Key Words: PUREX,

H-Canyon Modified (HM),

Retrieval,

Fissile,

Neutron Poisons

Caustic Leaching,

Corrosion

\title{
Dissolution of Simulated and Radioactive Savannah River Site High-Level Waste Sludges with Oxalic Acid and Citric Acid Solutions
}

M. E. Stallings

D. T. Hobbs

B. J. Wiersma

March 26, 2004

Westinghouse Savannah River Company

Savannah River Site

Aiken, SC 29808

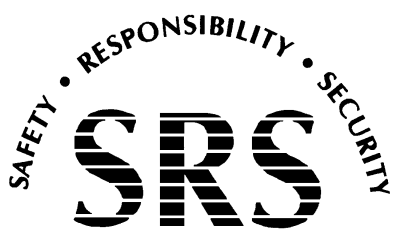

SAVANNAH RIVER SITE

Prepared for the U.S. Department of Energy Under

Contract Number DE-AC09-96SR18500 
This document was prepared in conjunction with work accomplished under Contract No. DE-AC09-96SR18500 with the U. S. Department of Energy.

\section{DISCLAIMER}

This report was prepared as an account of work sponsored by an agency of the United States Government. Neither the United States Government nor any agency thereof, nor any of their employees, makes any warranty, express or implied, or assumes any legal liability or responsibility for the accuracy, completeness, or usefulness of any information, apparatus, product or process disclosed, or represents that its use would not infringe privately owned rights. Reference herein to any specific commercial product, process or service by trade name, trademark, manufacturer, or otherwise does not necessarily constitute or imply its endorsement, recommendation, or favoring by the United States Government or any agency thereof. The views and opinions of authors expressed herein do not necessarily state or reflect those of the United States Government or any agency thereof.

This report has been reproduced directly from the best available copy.

Available for sale to the public, in paper, from: U.S. Department of Commerce, National Technical Information Service, 5285 Port Royal Road, Springfield, VA 22161, phone: (800) 553-6847, fax: (703) 605-6900

email: orders@ntis.fedworld.gov

online ordering: http://www.ntis.gov/help/index.asp

Available electronically at http://www.osti.gov/bridge

Available for a processing fee to U.S. Department of Energy and its contractors, in paper, from: U.S. Department of Energy, Office of Scientific and Technical Information, P.O. Box 62, Oak Ridge, TN 37831-0062,

phone: (865)576-8401,

fax: (865)576-5728

email: $\underline{\text { reports@ adonis.osti.gov }}$ 


\subsection{Summary}

This report presents findings from tests investigating the dissolution of simulated and radioactive Savannah River Site sludges with 4 wt \% oxalic acid and mixtures of oxalic and citric acid previously recommended by a Russian team from the Khlopin Radium Institute and the Mining and Chemical Combine (MCC). Testing also included characterization of the simulated and radioactive waste sludges. Testing results showed the following:

- Dissolution of simulated HM and PUREX sludges with oxalic and citric acid mixtures at SRTC confirmed general trends reported previously by Russian testing.

- Unlike the previous Russian testing six sequential contacts of a mixture of oxalic acid citric acids at a 2:1 ratio (v/w) of acid to sludge did not produce complete dissolution of simulated HM and PUREX sludges.

- We observed that increased sludge dissolution occurred at a higher acid to sludge ratio, 50:1 (v/w), compared to the recommended ratio of 2:1 (v/w).

- We observed much lower dissolution of aluminum in a simulated HM sludge by sodium hydroxide leaching. We attribute the low aluminum dissolution in caustic to the high fraction of boehmite present in the simulated sludge.

- Dissolution of HLW sludges from Tank 8F (PUREX) and 12H (HM) with 4 wt \% oxalic acid and oxalic/citric acid followed general trends observed with simulated sludges. The limited testing suggests that a mixture of oxalic and citric acids is more efficient for dissolving HM and PUREX sludges and provides a more homogeneous dissolution of HM sludge than oxalic acid alone.

- Dissolution of HLW sludges in oxalic and oxalic/citric acid mixtures produced residual sludge solids that measured at higher neutron poison to equivalent ${ }^{235} \mathrm{U}$ weight ratios than that in the untreated sludge solids. This finding suggests that residual solids do not present an increased nuclear criticality safety risk.

- Generally the neutron poison to equivalent ${ }^{235} \mathrm{U}$ weight ratios of the acid solutions containing dissolved sludge components are lower than those in the untreated sludge solids. We recommend that these results be evaluated further to determine if these solutions contain sufficient neutron poisons.

- We observed low general corrosion rates in tests in which carbon steel coupons were contacted with solutions of oxalic acid, citric acid and mixtures of oxalic and citric acids. Wall thinning can be minimized by maintaining short contact times with these acid solutions.

We recommend additional testing with oxalic and oxalic/citric acid mixtures to measure dissolution performance of sludges that have not been previously dried. This testing should include tests to clearly ascertain the effects of total acid strength and metal complexation on dissolution performance. Further work should also evaluate the downstream impacts of citric acid on the SRS High-Level Waste System (e.g., radiochemical separations in the Salt Waste Processing Facility and addition of organic carbon in the Saltstone and Defense Waste Processing facilities). 


\subsection{INTRODUCTION}

The Department of Energy previously funded Russian organizations at the V. G. Khlopin Radium Institute (St. Petersburg) and the Mining and Chemical Combine (Zheleznorgorsk) to investigate chemical methods for the dissolution of SRS sludge wastes. ${ }^{1}$ Based on this work, the Russian researchers recommended a solution consisting of oxalic and citric acids. Furthermore, the Russian researchers recommended that wastes high in aluminum first be contacted with a heated caustic solution. This caustic leach reduces the aluminum content in the sludge allowing more effective dissolution of other components by the oxalic and citric acids. The Russian investigators concluded that the oxalic acid and citric acid solution represented a viable means to dissolve simulated SRS high level waste sludges at conditions that pose minimal corrosion hazard for carbon steel and sufficiently uniform dissolution of fissile material and neutron poisons deemed necessary to maintain nuclear safety.

Subsequently, the Tanks Focus Area (TFA) funded Westinghouse Savannah River Company (WSRC) to conduct tests at the Savannah River Technology Center (SRTC) to confirm dissolution characteristics of oxalic and citric acid solutions with simulated and radioactive SRS sludges at the conditions recommended by the Russian team. ${ }^{2}$ In addition to the recommended 2:1 volume ratio of acid solution to sludge slurry, we tested a higher acid: sludge ratio (50:1). The higher ratio represents a bounding condition expected during heel removal operations in SRS waste tanks. We evaluated effectiveness of the oxalic/citric acid mixtures by comparison with dissolution in $4 \mathrm{wt} \%$ oxalic acid. This concentration of oxalic acid was studied previously in support of the Tank $16 \mathrm{H}$ chemical cleaning process. ${ }^{3}$

\subsection{EXPERIMENTAL}

\subsection{Preparation of Simulated Sludges}

Tests used non-radioactive mixtures that simulate sludge wastes produced from the PUREX and the H Canyon-Modified PUREX (HM) separation processes. Both of these processes employ solvent extraction to separate plutonium and uranium from irradiated nuclear fuels. This process contacts tri-n-butyl phosphate, in a nonvolatile solvent, with a concentrated nitric acid solution containing plutonium, uranium, and other fission products. Plutonium and uranium extract into the organic phase, leaving the fission products in the aqueous phase. A modification of the PUREX process, referred to as the H-Canyon Modified PUREX or HM process separates nuclear fuels containing highly enriched uranium. ${ }^{4}$ The process at the Savannah River Site discards fission products and chemical by-products from the separation processes into carbon steel waste tanks after adding concentrated sodium hydroxide to produce a highly alkaline waste suspension.

Tables 3.1 and 3.2 provide the chemical concentrations of the metals and oxyanions as well as a list of the chemical sources for the simulated PUREX and HM sludges, respectively. After dissolving each of these chemicals we added $50 \mathrm{wt} \%$ sodium hydroxide to bring the $\mathrm{pH}$ to $\geq 10.5$. The addition of caustic precipitates the bulk of the metals as the respective metal hydroxides and hydrous oxides. We then heated the mixtures to boiling for 24 hours, 
followed by cooling to room temperature and storing in stoppered plastic bottles. Boiling for 24 hours provides some degree of ripening and crystallization of the precipitated solids. The degree of ripening and crystallization is not representative of that which sludge solids receive during storage in HLW tanks. Sludge solids in HLW tanks experience elevated temperatures for prolonged periods (months/years). Table 4.2.4 provides the theoretical composition (wt $\%$ ) of the sludge solids for both simulants.

Table 3.1 Metal and Oxyanion Concentrations and Source Chemicals in the Simulated PUREX Sludge

\begin{tabular}{|c|c|c|}
\hline Component & Source & Concentration (M) \\
\hline $\mathrm{Fe}$ & $\mathrm{Fe}\left(\mathrm{NO}_{3}\right)_{3} \bullet 9 \mathrm{H}_{2} \mathrm{O}$ & 0.837 \\
\hline $\mathrm{Al}$ & $\mathrm{Al}\left(\mathrm{NO}_{3}\right)_{3} \bullet 9 \mathrm{H}_{2} \mathrm{O}$ & 0.221 \\
\hline $\mathrm{Mn}$ & $\mathrm{KMn} 0_{4}$ & 0.169 \\
\hline $\mathrm{Mn}$ & $\mathrm{Mn}\left(\mathrm{NO}_{3}\right)_{2} \bullet(50 \%$ soln. $)$ & 0.503 \\
\hline $\mathrm{Ca}$ & $\mathrm{Ca}\left(\mathrm{NO}_{3}\right)_{2} \bullet 4 \mathrm{H}_{2} 0$ & 0.010 \\
\hline $\mathrm{Mg}$ & $\mathrm{Mg}\left(\mathrm{NO}_{3}\right)_{2} \bullet 6 \mathrm{H}_{2} 0$ & 0.026 \\
\hline $\mathrm{SO}_{4}{ }^{2-}$ & $\mathrm{Na}_{2} \mathrm{SO}_{4} \bullet 10 \mathrm{H}_{2} \mathrm{O}$ & 0.017 \\
\hline $\mathrm{PO}_{4}{ }^{3-}$ & $\mathrm{Na}_{3} \mathrm{PO}_{4} \bullet 12 \mathrm{H}_{2} \mathrm{O}$ & 0.025 \\
\hline $\mathrm{Si}_{3}{ }^{2-}$ & $\mathrm{Na}_{2} \mathrm{Si}_{3} \bullet \bullet \mathrm{H}_{2} \mathrm{O}$ & 0.003 \\
\hline $\mathrm{Ni}$ & $\mathrm{Ni}\left(\mathrm{NO}_{3}\right)^{\bullet} 6 \mathrm{H}_{2} \mathrm{O}$ & 0.899 \\
\hline $\mathrm{Hg}$ & $\mathrm{Hg}\left(\mathrm{NO}_{3}\right)_{2} \bullet \mathrm{H}_{2} \mathrm{O}$ & 0.002 \\
\hline
\end{tabular}

Table 3.2 Metal and Oxyanion Concentrations and Source Chemicals in the Simulated HM Sludge

\begin{tabular}{|c|c|c|}
\hline Component & Source & Concentration (M) \\
\hline $\mathrm{Fe}$ & $\mathrm{Fe}\left(\mathrm{NO}_{3}\right)_{3} \bullet 9 \mathrm{H}_{2} \mathrm{O}$ & 0.175 \\
\hline $\mathrm{Al}$ & $\mathrm{Al}\left(\mathrm{NO}_{3}\right)_{3} \bullet 9 \mathrm{H}_{2} \mathrm{O}$ & 1.505 \\
\hline $\mathrm{Mn}$ & $\mathrm{KMnO}_{4}$ & 0.036 \\
\hline $\mathrm{Mn}$ & $\mathrm{Mn}\left(\mathrm{NO}_{3}\right)_{2} \bullet(50 \%$ sol $)$ & 0.109 \\
\hline $\mathrm{Ca}$ & $\mathrm{Ca}\left(\mathrm{NO}_{3}\right)_{2} \bullet 4 \mathrm{H}_{2} \mathrm{O}$ & 0.011 \\
\hline $\mathrm{Mg}$ & $\mathrm{Mg}\left(\mathrm{NO}_{3}\right)_{2} \bullet 6 \mathrm{H}_{2} \mathrm{O}$ & 0.012 \\
\hline $\mathrm{SO}_{4}{ }^{2-}$ & $\mathrm{Na}_{2} \mathrm{SO}_{4} \bullet 10 \mathrm{H}_{2} 0$ & 1.000 \\
\hline $\mathrm{PO}_{4}{ }^{3-}$ & $\mathrm{Na}_{3} \mathrm{PO}_{4} \bullet 12 \mathrm{H}_{2} 0$ & 0.001 \\
\hline $\mathrm{SiO}{ }_{3}{ }^{2-}$ & $\mathrm{Na}_{2} \mathrm{SiO}_{3} \bullet 9 \mathrm{H}_{2} 0$ & 0.015 \\
\hline $\mathrm{Ni}$ & $\left.\mathrm{Ni}_{(} \mathrm{NO}_{3}\right) \bullet 6 \mathrm{H}_{2} 0$ & 0.016 \\
\hline $\mathrm{Hg}$ & $\mathrm{Hg}\left(\mathrm{NO}_{3}\right)_{2} \bullet \mathrm{H}_{2} 0$ & 0.026 \\
\hline
\end{tabular}

\subsection{Archived HLW Sludge Samples}

Radioactive testing utilized archived sludge samples from Tanks 8F (PUREX) and 12H (HM). These samples had previously been dried to remove free water and stored in stainless steel containers at the SRTC Shielded Cell facility. We received 160-gram sub-samples of 
each archived sludge material. We ground each sample in a mortar and pestle to a fine powder form and placed in a clean glass container. A representative sample was taken from the jar and prepared for analysis by two independent dissolution methods, sodium peroxide fusion and microwave digestion in triplicate. Analytical methods used to characterize the sludges included the following: (1) Inductively Coupled Plasma Emission Spectroscopy (ICP-ES), (2) Inductively Coupled Plasma-Mass Spectrometry (ICP-MS), (3) Atomic Absorption Spectroscopy (AA), (4) Gamma counting, (5) Alpha pulse height counting for plutonium after extraction using thenoyltriflouroacetone (PuTTA) and (6) gross alpha and beta counting. All samples prepared for the characterization analyses required an additional 50-fold dilution with $2 \mathrm{M}$ nitric acid to reduce radiation levels for handling in radiohoods/radiobenches outside of the Shielded Cells facility.

\subsection{Oxalic and Citric Acid Solutions}

Dissolution tests featured solutions comprised of either a mixture of oxalic and citric acids or a 4 wt \% (0.4 M) solution of oxalic acid. Dissolution of PUREX sludges featured an oxalic/citric acid solution comprised of $15 \mathrm{~g} / \mathrm{L}$ of oxalic acid $(0.167 \mathrm{M})$ and $15 \mathrm{~g} / \mathrm{L}$ of citric acid monohydrate $(0.071 \mathrm{M})$. Dissolution of HM sludge used a more dilute solution comprised on $5 \mathrm{~g} / \mathrm{L}$ oxalic acid $(0.056 \mathrm{M})$ and $5 \mathrm{~g} / \mathrm{L}$ citric acid monohydrate $(0.024 \mathrm{M})$. All solution preparations use reagent grade chemicals and deionized, distilled water.

\subsection{Caustic Leaching Solution}

Aluminum leaching of the simulated HM sludge featured a $2 \mathrm{M}$ solution of sodium hydroxide prepared using reagent grade sodium hydroxide and deionized, distilled water.

\subsection{Dissolution Tests with Simulated Sludges}

Researchers employed two experimental methods to test the effectiveness of the oxalic acid citric acid solutions to dissolve simulated sludges. For the first set of tests, we placed a measured quantity of the simulated sludge slurry into a clean polypropylene centrifuge tube followed by the appropriate quantity of caustic solution or acid solution to provide a volume ratio of acid solution to the sludge slurry weight at $2: 1$ or 50:1. During contacts with the acid solutions, personnel measured the $\mathrm{pH}$ of the resultant mixture and added a small quantity of sodium hydroxide solution to adjust the initial $\mathrm{pH}$ to 4.2 as recommended by the Russian researchers. ${ }^{1}$ We capped the tube and placed it into a New Brunswick Scientific C-24 incubator shaker set at $200 \mathrm{rpm}$ and $60{ }^{\circ} \mathrm{C}$. After agitating for 7 hours, we centrifuged each tube using a Marathon Centrifuge model $8 \mathrm{~K}$ at $2500 \mathrm{rpm}$ for 15 minutes and carefully pipetted off all of the supernatant liquid free of settled sludge solids.

At this point the supernatant liquid includes liquids arising from the original sludge slurry as well as those from the caustic and acid solutions. We submitted portions of the supernatant liquid for elemental analysis using inductively coupled plasma emission spectroscopy (ICPES). We repeated the process with fresh caustic or acid solutions until one of the following conditions occurred: (1) a total of 3 contacts with $2 \mathrm{M}$ sodium hydroxide solution and (2) a maximum of six acid solution contacts. After the six contacts with the oxalic/citric acid solution, we dried the remaining solids at $100^{\circ} \mathrm{C}$. We characterized the dried solids by X-ray 
diffraction (XRD) for identification of crystalline phases. The authors performed replicate tests for each sludge type.

The second experimental method featured a water wash (5-mL deionized water) between each sequential acid addition and the inclusion of tests using 4 wt \% oxalic acid. In addition a seventh contact was added to observe if more acid additions would promote greater dissolution of the simulated sludge solids. We analyzed each contact solution for elemental composition using ICP-ES. From the elemental analysis and volume of each contact solution, we determined the quantity of the four principal metals ( $\mathrm{Fe}, \mathrm{Al}, \mathrm{Mn}$ and $\mathrm{Ni}$ ) in the sludge solids. Note that for Al, about $15 \mathrm{wt} \%$ of the total $\mathrm{Al}$ in the sludge slurry is dissolved in the supernate. Thus, the reported percentage of dissolved aluminum in the first contact with the simulated HM sludge includes the Al that is dissolved in the supernate.

\subsection{Dissolution Tests with Radioactive Sludges}

Dissolution tests with radioactive sludges followed a similar methodology as described in the section 3.5. We performed duplicate tests with each acid solution. We performed these tests at acid to sludge ratios on a volume to weight basis, either $2: 1$ or 50:1 (e.g., $20 \mathrm{~mL}$ of acid solution to $10 \mathrm{~g}$ of dried sludge). Also, we omitted the $\mathrm{pH}$ adjustment with all radioactive sludge testing after evaluating the feasibility to perform adjustments in actual HLW operations and concluding that such an adjustment would be impractical. The isolated acidic solutions from the dissolution tests required dilution with $2 \mathrm{M}$ nitric acid to reduce the radioactivity for safe handling outside of the Shielded Cells facility. The diluted solutions were analyzed by ICP-MS for actinides and ICP-ES for a variety of elements.

\subsection{Computation of Equivalent ${ }^{235} \mathrm{U}$ Content}

To address the efficiency of the citric acid and oxalic acid solutions to dissolve both neutron poisons ( $\mathrm{Al}, \mathrm{Fe}, \mathrm{Mn}, \mathrm{Ni}$ and $\mathrm{Na}$ ) and fissionable/fissile radioisotopes we calculated the weight ratio of each neutron poison to equivalent ${ }^{235} \mathrm{U}$ concentration in the acid solutions. We calculated the equivalent ${ }^{235} \mathrm{U}$ using the following equation from the ICP-MS results:

Equivalent $\left[{ }^{235} \mathrm{U}\right](\mathrm{wt} \%)=\left[{ }^{233} \mathrm{U}\right]+\left[{ }^{235} \mathrm{U}\right]+4 *\left[{ }^{239} \mathrm{Pu}\right]$,

where each of the isotope concentrations is expressed in wt $\%$.

\subsection{Analytical Methods}

Inductively coupled plasma emission spectrometry (ICP-ES) provided the determination of the elemental content in the solutions derived from the acid and caustic dissolution tests. Elemental analysis of the sludge solids followed dissolution by standard methods developed by the Analytical Development Section of SRTC for the dissolution of SRS HLW sludges. Cold Vapor Atomic Absorption Spectrometry provided the determination of mercury. X-Ray Diffraction (XRD) analysis identified the presence of crystalline phases in the sludge solids. XRD analysis was performed on dried solids separated from the liquid fraction of the slurry, washed with deionized distilled water and air dried at ambient laboratory temperature. XRD spectra provided in this report include color-coded diffraction pattern lines of known 
chemical substances that were identified by spectral fitting software to best represent the crystalline phases in the dried solids.

\subsection{RESULTS AND DISCUSSION}

\subsection{Characterization of Simulated Sludges}

Chemical and X-ray diffraction analyses indicated that the simulated PUREX and HM sludges are composed of non-silicate material, mainly sodium, iron and aluminum. The only crystalline phase found in the simulated PUREX sludge is nitratine, which is a mineral phase of sodium nitrate (See Figure 4.1.1). Sodium nitrate is a byproduct from the sludge preparation in which we combined metal nitrate salts and sodium hydroxide. The bulk of the sodium nitrate resides in the solution phase; however, a small amount may be occluded within the sludge solids. The crystalline phases identified in the HM simulant included sodium nitrate, mercury oxide, boehmite and hematite (see Figure 4.1.2). Note that the aluminum phase present in the HM sludge existed primarily as boehmite and not gibbsite. Boehmite exhibits a lower solubility in alkaline solutions. Consequently, sludges with higher fractions of boehmite require more rigorous conditions (e.g., higher $\mathrm{OH} \bullet$ concentration and temperature) and longer leaching times to yield aluminum removal comparable to that observed with sludges rich in gibbsite. ${ }^{5}$

Table 4.1.1 provides a summary of the elemental composition measured by ICP-ES, specific gravity and $\mathrm{pH}$ for the simulated PUREX and HM sludge slurries. Note that the reported results are on a total slurry basis and not on a sludge solids basis. The PUREX simulant contained a higher iron, manganese and nickel concentration compared to the HM simulant. Aluminum proved the dominant element in the HM simulant. Both simulants are alkaline, (pH of PUREX slurry measured 10.2 and that of the HM slurry measured 11.0). The specific gravity of the PUREX slurry measured 1.22 versus a value of $1.38 \mathrm{~g} / \mathrm{mL}$ for the HM sludge.

Table 4.1.2 shows selected elements for the PUREX and HM simulants prepared at SRTC and at the Russian laboratories versus that calculated based on the simulant recipe. The results show excellent agreement between the theoretical elemental composition and the measured values for both the SRTC and Russian prepared PUREX sludges. Results for the HM sludges indicate poorer agreement between the theoretical and measured elemental composition.

The SRTC prepared sludge measured low in aluminum and high in iron, manganese and nickel. The Russian simulant measured high in aluminum and manganese and low in iron and nickel. These differences may reflect the final free hydroxide concentration of the slurry. In the case of the SRTC preparation, the final free hydroxide concentration was perhaps higher, resulting in more aluminum dissolved in solution leaving less aluminum in the sludge solids. Conversely, the Russian preparation was low in hydroxide concentration, resulting in less aluminum in solution and more aluminum in the sludge solids. 
Figure 4.1.1 X-Ray Diffraction Spectrum of the Simulated PURX Sludge Including Identification of Crystalline Phases

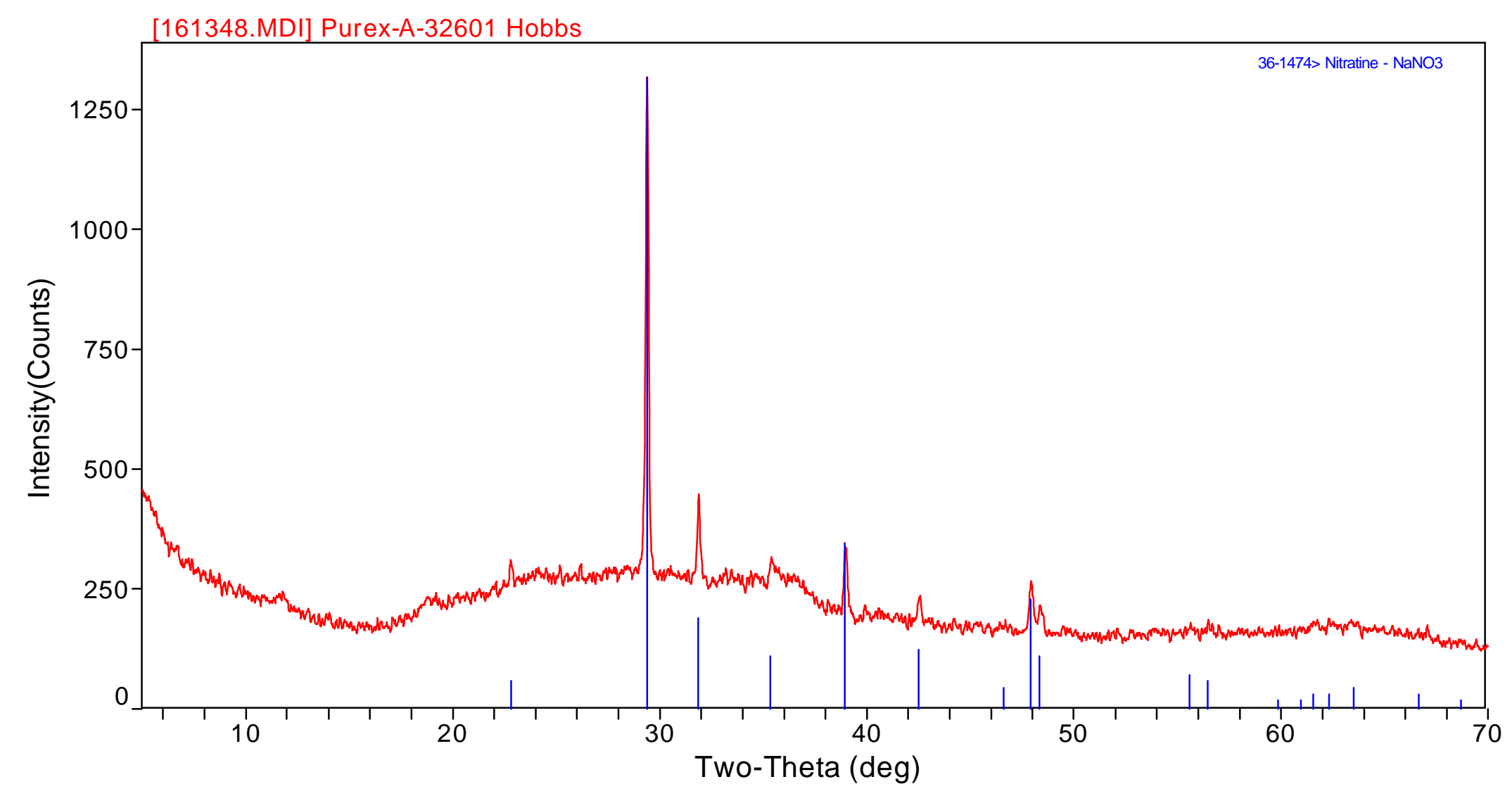


Figure 4.1.2 X-Ray Diffraction Spectrum of the Simulated HM Sludge Including Identification of Crystalline Phases

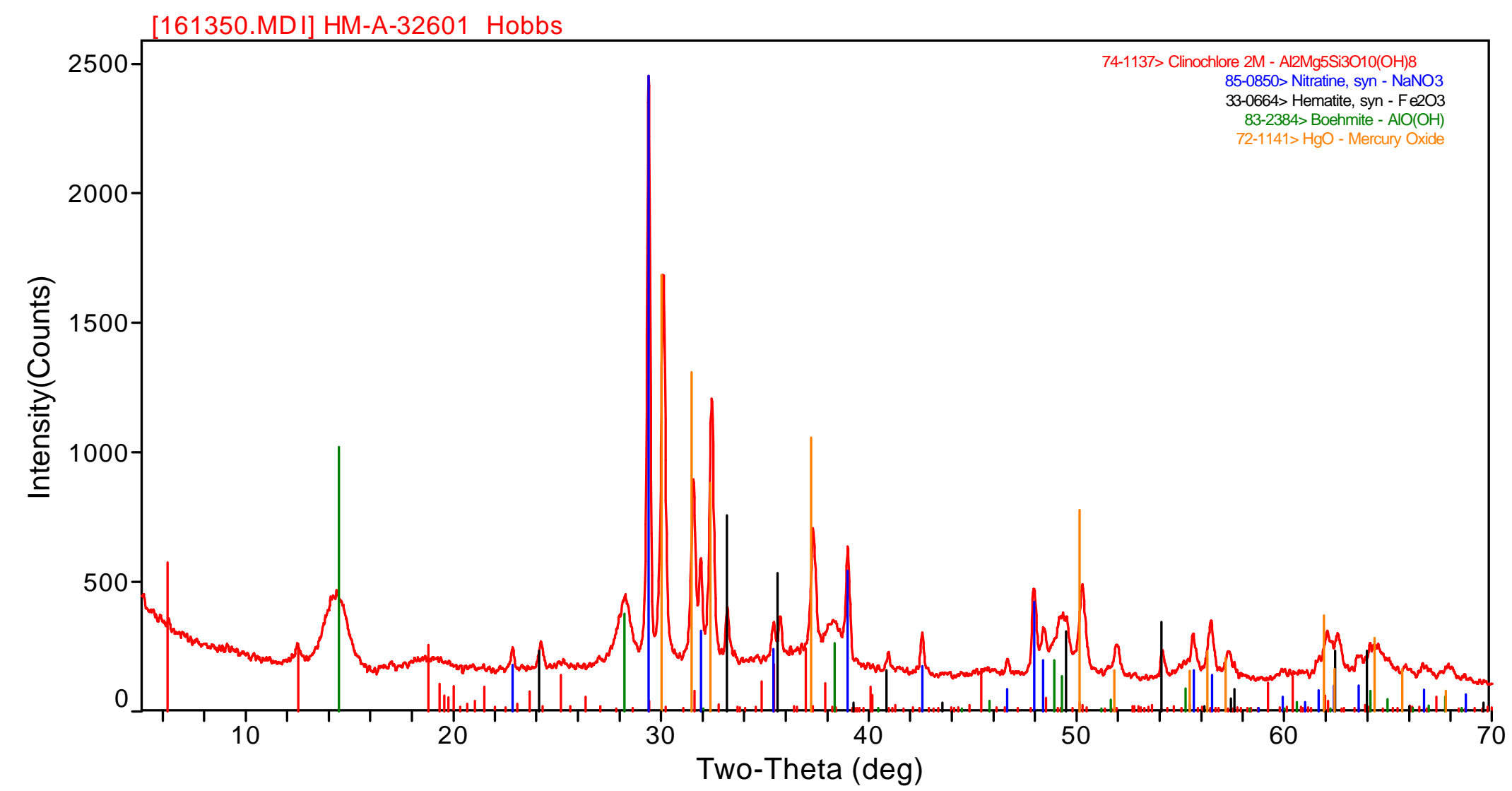


Table 4.1.1 Elemental Composition and Selected Other Properties of the Simulated PUREX and HM Sludge Slurries ${ }^{\mathrm{a}}$

\begin{tabular}{|c|c|c|c|c|}
\hline $\begin{array}{l}\text { Elemental } \\
\text { Species }\end{array}$ & $\begin{array}{c}\text { Simulated PUREX } \\
\text { Sludge }\end{array}$ & $\begin{array}{c}\text { Simulated } \\
\text { PUREX Sludge }\end{array}$ & $\begin{array}{l}\text { Simulated } \\
\text { HM Sludge }\end{array}$ & $\begin{array}{l}\text { Simulated } \\
\text { HM Sludge }\end{array}$ \\
\hline & wt $\%$ & mole/g & wt $\%$ & mole/g \\
\hline $\mathrm{Al}$ & 0.456 & $1.69 \mathrm{E}-04$ & 2.72 & $1.01 \mathrm{E}-03$ \\
\hline B & bdl & bdl & bdl & bdl \\
\hline $\mathrm{Ba}$ & bdl & bdl & bdl & bdl \\
\hline $\mathrm{Ca}$ & 0.031 & 7.73E-06 & 0.051 & $1.27 \mathrm{E}-05$ \\
\hline $\mathrm{Cd}$ & bdl & bdl & bdl & bdl \\
\hline $\mathrm{Cu}$ & bdl & bdl & bdl & bdl \\
\hline $\mathrm{Fe}$ & 3.68 & $6.59 \mathrm{E}-04$ & 1.17 & $2.10 \mathrm{E}-04$ \\
\hline $\mathrm{Li}$ & bdl & bdl & bdl & bdl \\
\hline $\mathrm{Mg}$ & 0.046 & $1.91 \mathrm{E}-05$ & 0.034 & $1.38 \mathrm{E}-05$ \\
\hline $\mathrm{Mn}$ & 1.81 & $3.29 \mathrm{E}-04$ & 0.600 & $1.09 \mathrm{E}-04$ \\
\hline Mo & bdl & bdl & bdl & bdl \\
\hline $\mathrm{Na}$ & 5.84 & $2.53 \mathrm{E}-03$ & 9.840 & $4.28 \mathrm{E}-03$ \\
\hline $\mathrm{Ni}$ & 0.426 & $7.26 \mathrm{E}-05$ & 0.110 & $1.87 \mathrm{E}-05$ \\
\hline $\mathrm{P}$ & bdl & bdl & bdl & bdl \\
\hline $\mathrm{Pb}$ & bdl & bdl & bdl & bdl \\
\hline $\mathrm{Si}$ & 0.011 & $3.95 \mathrm{E}-06$ & 0.046 & $1.64 \mathrm{E}-05$ \\
\hline $\mathrm{Sr}$ & bdl & bdl & bdl & bdl \\
\hline $\mathrm{Ti}$ & bdl & bdl & bdl & bdl \\
\hline V & bdl & bdl & bdl & bdl \\
\hline $\mathrm{Zn}$ & bdl & bdl & bdl & bdl \\
\hline $\mathrm{Zr}$ & bdl & bdl & bdl & bdl \\
\hline $\mathrm{La}$ & bdl & bdl & bdl & bdl \\
\hline $\mathrm{Hg}$ & 0.039 & $1.89 \mathrm{E}-06$ & 0.378 & $1.88 \mathrm{E}-05$ \\
\hline Total Solids & 30.0 & & 52.0 & \\
\hline $\begin{array}{l}\text { Dissolved } \\
\text { Solids }\end{array}$ & 18.1 & & 42.4 & \\
\hline $\begin{array}{l}\text { Insoluble } \\
\text { Solids }\end{array}$ & 11.9 & & 9.59 & \\
\hline $\begin{array}{l}\text { Slurry } \\
\text { Density } \\
(\mathrm{g} / \mathrm{mL})\end{array}$ & 1.22 & & 1.38 & \\
\hline $\mathrm{pH}$ & 10.2 & & 11.0 & \\
\hline
\end{tabular}

a composition based on total slurry basis

bdl $=$ below detection limits 
Table 4.2.4 Comparison of Selected Elemental Components for the SRTC PUREX and HM Simulated Sludge Slurries and Russian PUREX and HM Simulated Sludge Slurries

\begin{tabular}{|c|c|c|c|c|c|c|}
\hline Element & $\begin{array}{c}\text { SRTC } \\
\text { PUREX } \\
\text { Simulant } \\
\text { Theoretical } \\
\text { (wt \%) } \\
\end{array}$ & $\begin{array}{c}\text { SRTC } \\
\text { PUREX } \\
\text { Simulant } \\
\text { Measured } \\
\text { (wt \%) } \\
\end{array}$ & $\begin{array}{c}\text { Russian } \\
\text { PUREX } \\
\text { Simulant } \\
\text { Measured } \\
\text { (wt \%) } \\
\end{array}$ & $\begin{array}{c}\text { SRTC } \\
\text { HM } \\
\text { Simulant } \\
\text { Theoretical } \\
\text { (wt \%) } \\
\end{array}$ & $\begin{array}{c}\text { SRTC } \\
\text { HM } \\
\text { Simulant } \\
\text { Measured } \\
\text { (wt \%) } \\
\end{array}$ & $\begin{array}{l}\text { Russian } \\
\text { HM } \\
\text { Simulant } \\
\text { Measured } \\
\text { (wt \%) } \\
\end{array}$ \\
\hline $\mathrm{Al}$ & 7.21 & 7.02 & 6.57 & 64.8 & 53.2 & 70.6 \\
\hline $\mathrm{Fe}$ & 56.5 & 56.6 & 54.0 & 15.6 & 27.9 & 11.2 \\
\hline $\mathrm{Mg}$ & 0.78 & 0.71 & 0.69 & 0.48 & 0.66 & 0.40 \\
\hline $\mathrm{Mn}$ & 27.9 & 27.8 & 30.6 & 7.96 & 11.8 & 9.11 \\
\hline $\mathrm{SiO}_{2}$ & $\mathrm{nr}$ & $\mathrm{nr}$ & 0.19 & $\mathrm{nr}$ & $\mathrm{nr}$ & 0.93 \\
\hline $\mathrm{Ni}$ & 6.37 & 6.55 & 6.06 & 1.47 & 2.15 & 1.05 \\
\hline $\mathrm{Hg}$ & 0.50 & 0.60 & 0.52 & 8.26 & 7.40 & 5.93 \\
\hline $\mathrm{Pu}$ & na & na & 0.13 & na & na & 0.32 \\
\hline $\mathrm{U}$ & na & na & 0.86 & na & na & 0.086 \\
\hline
\end{tabular}

${ }^{a}$ composition based on total slurry basis

$\mathrm{nr}=$ not reported due to HF leaching from ICP-ES torch, which results in high biased results. na $=$ element not added

\subsection{Characterization of SRS HLW Sludges from Tank 8F (PUREX) and}

\section{Tank 12H (HM)}

Table 4.2.1 and 4.2.2 provide a summary of the major elemental and radiochemical components measured in the Tank $8 \mathrm{~F}$ and Tank $12 \mathrm{H}$ sludge solids. The measured elemental composition is consistent with SRS PUREX and HM sludges in that iron serves as the predominant element in the PUREX sludge and aluminum is the predominant element in the HM sludge. The PUREX sludge has a high uranium content, which is consistent with the common practice to add depleted uranium as a neutron poison for plutonium. Mercury content is much higher in the HM sludge, which is consistent with the use of mercury as a catalyst in dissolving aluminum cladding from the fuel rods.

Table 4.2.1 Major Elemental Composition of the Tank 8F and Tank 12H Sludge Samples

\begin{tabular}{|c|c|c|}
\hline Elements & Tank 8F Sludge (PUREX) & Tank 12H Sludge (HM) \\
\hline & wt \% & wt \% \\
\hline $\mathrm{Al}$ & $2.55 \pm 0.0781$ & $35.1 \pm 0.71$ \\
\hline $\mathrm{F}$ & $19.0 \pm 0.469$ & $4.00 \pm 0.28$ \\
\hline $\mathrm{Mn}$ & $3.44 \pm 0.0455$ & $2.02 \pm 0.092$ \\
\hline $\mathrm{Ni}$ & $3.28 \pm 0.0572$ & $0.453 \pm 0.031$ \\
\hline $\mathrm{Hg}$ & $0.220 \pm 0.00525$ & $1.01 \pm 0.026$ \\
\hline $\mathrm{Na}$ & $9.66 \pm 0.619$ & $2.10 \pm 0.500$ \\
\hline $\mathrm{U}$ & $14.2 \pm 0.842$ & $0.0332 \pm 0.00234$ \\
\hline $\mathrm{Pu}$ & $4.51 \mathrm{E}-3 \pm 3.11 \mathrm{E}-05$ & $6.62 \mathrm{E}-02 \pm 5.02 \mathrm{E}-04$ \\
\hline
\end{tabular}


Table 4.2.3 compares the measured elemental compositions of the simulated PUREX and HM sludges (solids basis) with those of the archived HLW sludge samples. Iron is the predominant metal on a weight basis for both the simulated PUREX sludge and the Tank $8 \mathrm{~F}$ sample. For the simulated HM sludge and the Tank $12 \mathrm{H}$ sample aluminum is the principal metal component. Note that the Tank $8 \mathrm{~F}$ sample contained much less manganese than that in the simulated PUREX sludge and the Tank 12H sample contained much lower amounts of iron and mercury than those in the simulated HM sludge.

Table 4.2.3 Comparison of Selected Elemental Components for the PUREX and HM Simulated Sludges and Tank 8F and Tank 12H HLW Sludge Samples

\begin{tabular}{|c|c|c|c|c|}
\hline Elements & $\begin{array}{c}\text { PUREX Simulant } \\
(\mathbf{w t} \%)^{*}\end{array}$ & $\begin{array}{c}\text { Tank 8F Sludge } \\
(\mathbf{w t} \%)^{*}\end{array}$ & $\begin{array}{c}\text { HM Simulant } \\
(\mathbf{w t} \%)\end{array}$ & $\begin{array}{c}\text { Tank 12H } \\
\text { Sludge (wt \%) }\end{array}$ \\
\hline $\mathrm{Al}$ & 7.02 & 2.55 & 53.2 & 35.1 \\
\hline $\mathrm{Fe}$ & 35.6 & 19.0 & 27.9 & 4.00 \\
\hline $\mathrm{Mg}$ & 0.71 & $\mathrm{bdl}$ & 0.71 & 0.163 \\
\hline $\mathrm{Mn}$ & 27.8 & 3.44 & 11.8 & 2.02 \\
\hline $\mathrm{Na}$ & - & 9.66 & - & 2.10 \\
\hline $\mathrm{Ni}$ & 6.55 & 3.28 & 2.15 & 0.453 \\
\hline $\mathrm{Hg}$ & 0.60 & 0.220 & 7.40 & 1.01 \\
\hline
\end{tabular}

* wt \% on sludge solids basis

\subsection{Set \#1 Test Results with Simulated Sludge}

Table 4.3.1 provides a summary of the conditions and results for the first set of dissolution tests with suspensions of the simulated PUREX and HM sludges. We conducted duplicate tests for the dissolution of PUREX and HM sludges at acid to sludge slurry ratios (v/w) of 2:1 and 50:1. For each test, we performed six separate contacts of the sludge sample with the acid solution. Note that the volume of the acid or caustic solution remained constant for each contact. Thus the acid:sludge ratio increases with each successive contact given that each contact removes some fraction of sludge. For the HM sludge tests, we contacted the sludge three times with $2 \mathrm{M}$ caustic solution prior to contacting with the acid solution at the $2: 1 \mathrm{v} / \mathrm{W}$ ratio. We did not perform the caustic leaching with the HM sludge prior to contacting at a $50: 1 \mathrm{v} / \mathrm{w}$ ratio.

At the 2:1 ratio of acid to sludge, we measured the dissolution of both the PUREX and HM sludge solids at $73 \mathrm{wt} \%$. Previously, the Russian team reported $97.8 \%-99.7 \%$ dissolution of the PUREX sludge after 6 contacts and 99.9-100\% dissolution of the HM sludge after 5 contacts. These results suggest that the SRTC-prepared simulants contain a much higher fraction of recalcitrant solids (e.g., boehmite versus gibbsite) compared to that in the Russian-prepared materials. Increased sludge solids dissolution occurred with the 50:1 acid to sludge ratio with the SRS prepared sludge simulants. For the PUREX sludge, we measured $>99$ wt \% dissolution and $93-94$ wt \% dissolution of the HM sludge solids. 
Figure 4.3.1 provides a plot of the total concentration of metals in the acid solution at each contact for the duplicate 2:1 tests with the PUREX sludge simulant. The total metal concentrations increase consecutively during the first three contacts and decrease in the last two contacts. The decrease in the metal concentrations in the later contacts likely reflects a combination of less soluble solid phases and less available mass of sludge solids.

\section{Table 4.3.1 Summary of Test Set \#1 Conditions and Quantity of Sludge Dissolved}

\begin{tabular}{|c|c|c|c|c|c|}
\hline Test \# & $\begin{array}{c}\text { Sludge } \\
\text { Simulant }\end{array}$ & $\begin{array}{c}\text { Liquid to } \\
\text { Sludge Ratio } \\
(v / w)\end{array}$ & $\begin{array}{l}\text { Caustic } \\
\text { Leached }\end{array}$ & $\begin{array}{c}\text { Wt \% } \\
\text { Aluminum }^{\text {Dissolved }}\end{array}$ & $\begin{array}{c}\text { Wt \% } \\
\text { Insoluble } \\
\text { Solids } \\
\text { Dissolved }^{b}\end{array}$ \\
\hline 1 & PUREX & $2: 1$ & No & $n m$ & 74 \\
\hline 2 & PUREX & $2: 1$ & No & $n m$ & 72 \\
\hline 3 & PUREX & $50: 1$ & No & $n m$ & $>99$ \\
\hline 4 & PUREX & $50: 1$ & No & $n m$ & $>99$ \\
\hline 5 & $\boldsymbol{H} \boldsymbol{M}$ & $2: 1$ & Yes & 55 & 72 \\
\hline 6 & $H M$ & $2: 1$ & Yes & 56 & 73 \\
\hline 7 & $\boldsymbol{H} \boldsymbol{M}$ & $50: 1$ & No & $n m$ & 93 \\
\hline 8 & $\boldsymbol{H} \boldsymbol{M}$ & $50: 1$ & No & $n m$ & 94 \\
\hline
\end{tabular}

Figure 4.3.2 provides the results for the duplicate tests with the simulated PUREX sludge at a 50:1 ratio. The first contact dissolved the largest fraction of the sludge. The total metals concentrations in the $2^{\text {nd }}$ through the $5^{\text {th }}$ contacts were similar and measured much smaller than the $1^{\text {st }}$ contact. Overall, the quantity of PUREX sludge solids dissolved in the 50:1 tests measured about $25 \%$ higher than that in the 2:1 tests (see Table 4.3.1).

Three contacts of the HM sludge slurry with $2 \mathrm{M}$ sodium hydroxide at a 2:1 volume ratio heated to $60{ }^{\circ} \mathrm{C}$ resulted in an average dissolution of $56 \mathrm{wt} \%$ of the aluminum (see Table 4.3.1). This value agrees well with that reported by the Russian team upon caustic treatment of simulated SRS sludges. ${ }^{6}$ Complete dissolution of the aluminum would not be expected at the leaching conditions employed in these tests due to the presence of boehmite in the sludge. Infrared spectroscopy indicated that boehmite was the predominant aluminum phase in the simulated sludge. Dissolution of boehmite requires more rigorous conditions (e.g., higher $\mathrm{NaOH}$ concentration and higher temperatures). ${ }^{7}$ The presence of boehmite in the simulated sludge after caustic and acid contacts was confirmed by X-ray diffraction of the post-contact solids (see Figure 4.3.3) 
Figure 4.3.1 Total Concentration of Dissolved Metals upon Contact of Simulated PUREX Sludge with 2:1 Ratio of Oxalic/Citric Acid Solution

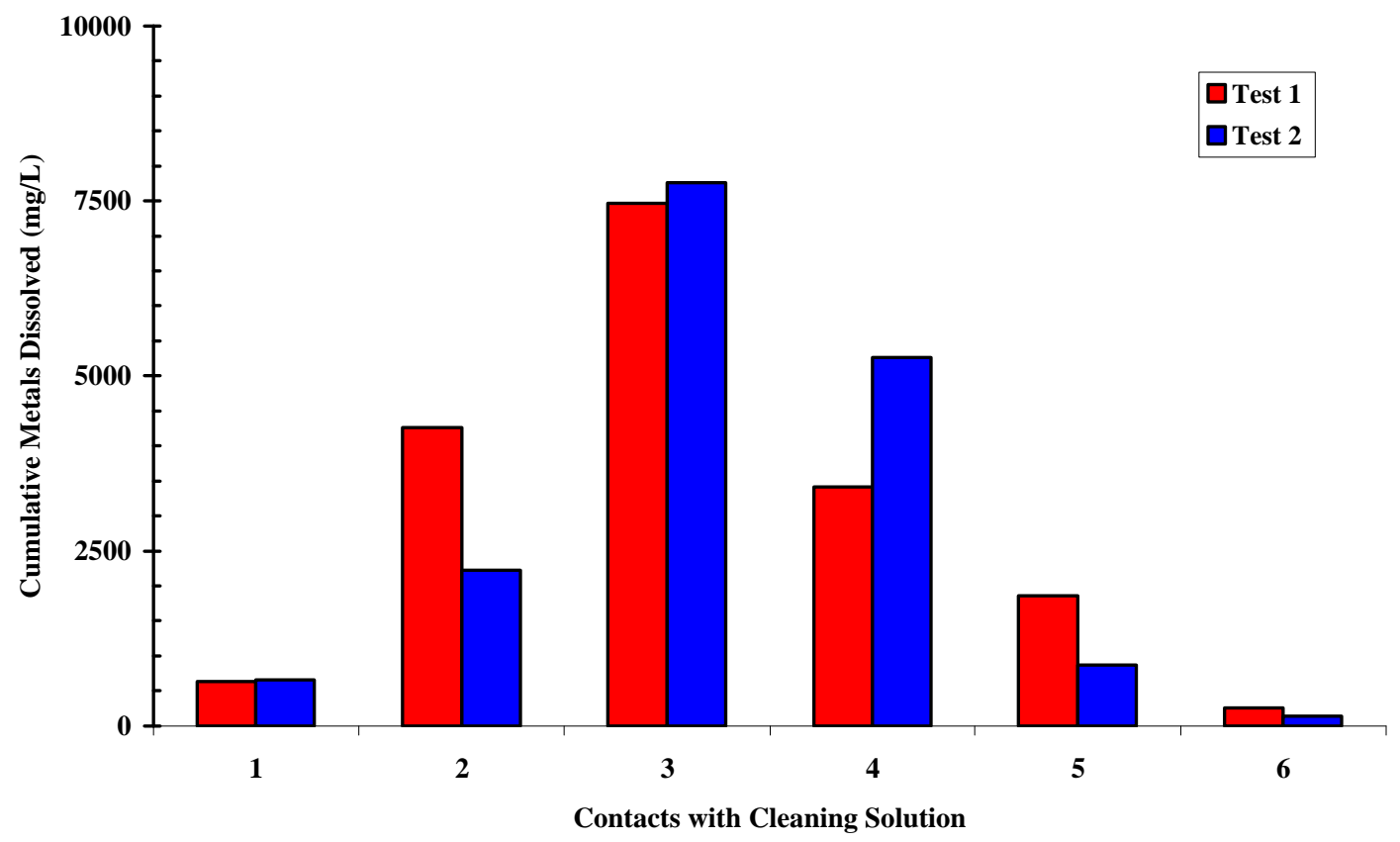

Figure 4.3.2 Total Concentration of Dissolved Metals upon Contact of Simulated PUREX Sludge with 50:1 Ratio of Oxalic/Citric Acid Solution

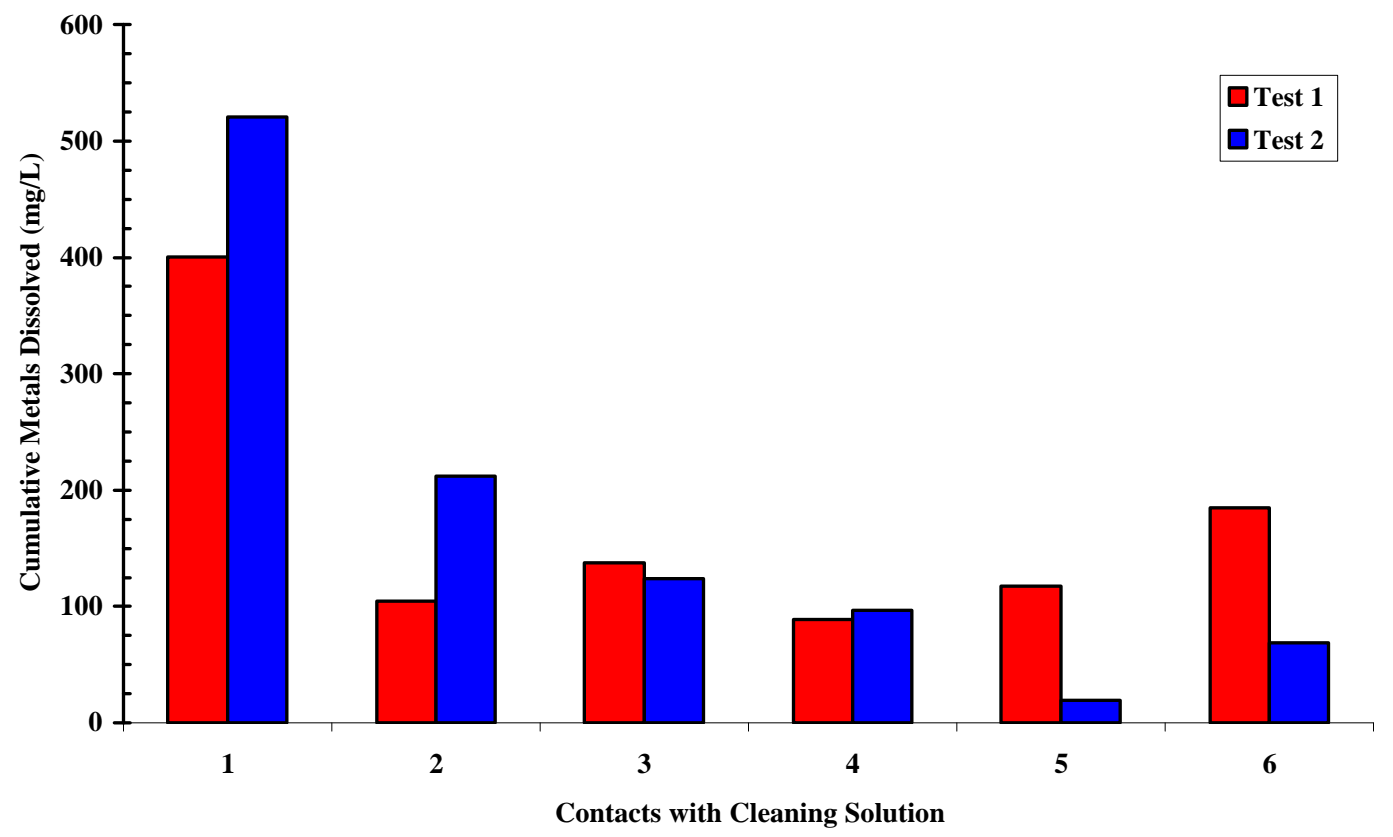


Figure 4.3.3 X-ray Diffraction Spectrum of the 2:1 Volume Ratio of the HM sludge After 3 Contacts with $2 \mathrm{M} \mathrm{NaOH}$ and 6 Contacts with Oxalic/Citric Acid Solution

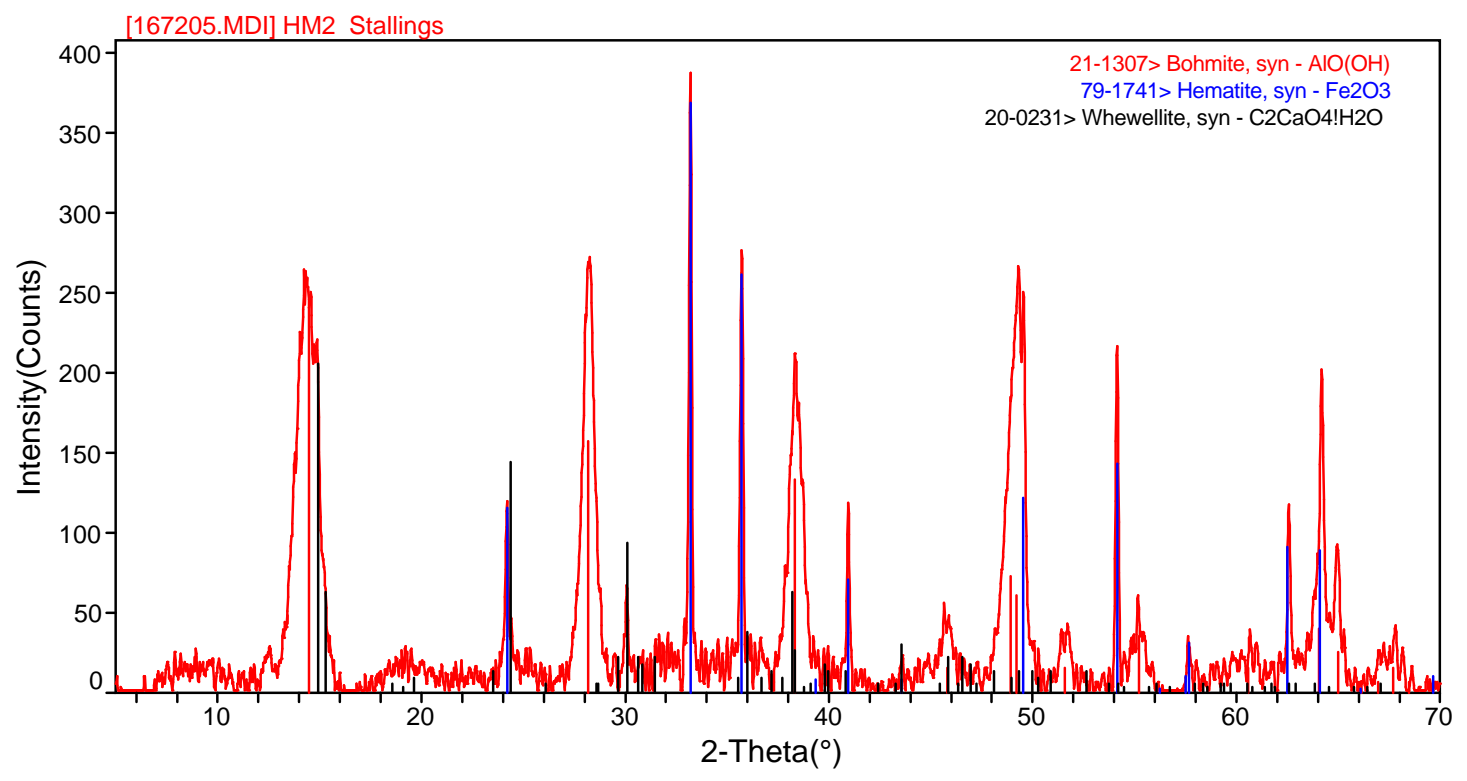

The dissolution of the sludge components, principally aluminum, decreased with successive contacts of the caustic solution (see Figure 4.3.4). The concentrations of other metals (e.g., iron, manganese and nickel) proved very low in the caustic solutions indicating little, if any, dissolution of these metals. The caustic solutions did contain appreciable amounts of sodium principally from the sodium salts that are present in the sludge slurries. 
Figure 4.3.4 Total Concentrations of Dissolved Metals upon Contact of Simulated HM sludge with 2:1 Ratio of 2M Sodium Hydroxide

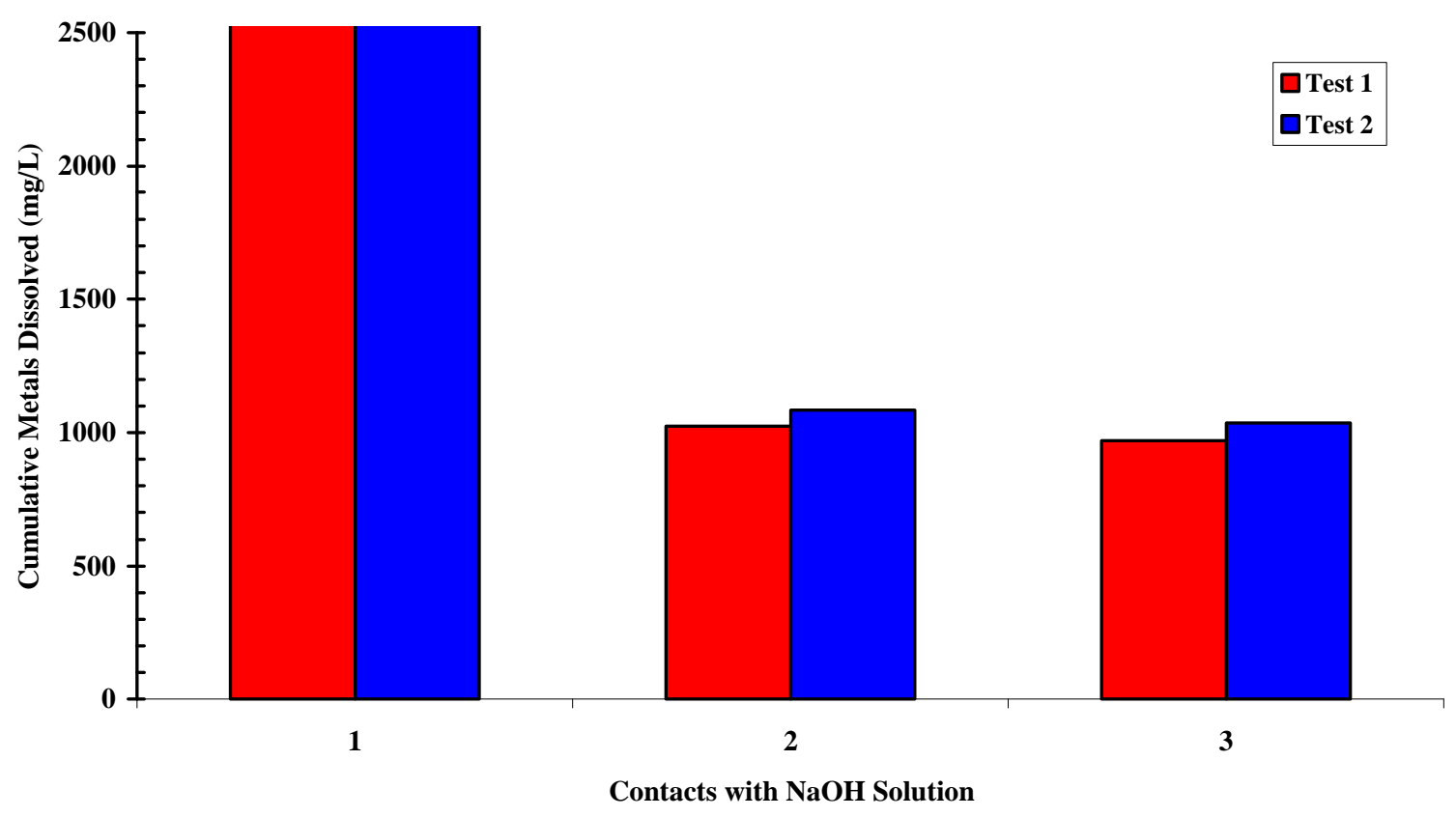

Figure 4.3.5 provides a plot of the total concentration of metals in the acid solution at each contact for the duplicate 2:1 tests with the HM sludge simulant after caustic leaching. The graph illustrates a gradual increase in metals dissolved from the $1^{\text {st }}$ contact through the $6^{\text {th }}$ and final contact. This trend is in contrast to that observed with the simulated PUREX waste, which increased steadily through the first 3 contact and then decreased with later contacts. Note also that the total metals concentrations in each of the contacts with the HM sludge are as large as or larger than those measured with the PUREX sludge even though the oxalic/citric acid mixture used in the HM sludge tests contains one-third the acid concentration used in the PUREX tests. This trend suggests that the HM sludge solids remaining after caustic leaching dissolve more readily than those in the PUREX sludge simulant. 
Figure 4.3.5 Total Concentrations of Dissolved Metals upon Contact of Simulated HM sludge with 2:1 Ratio of Oxalic/Citric Acid

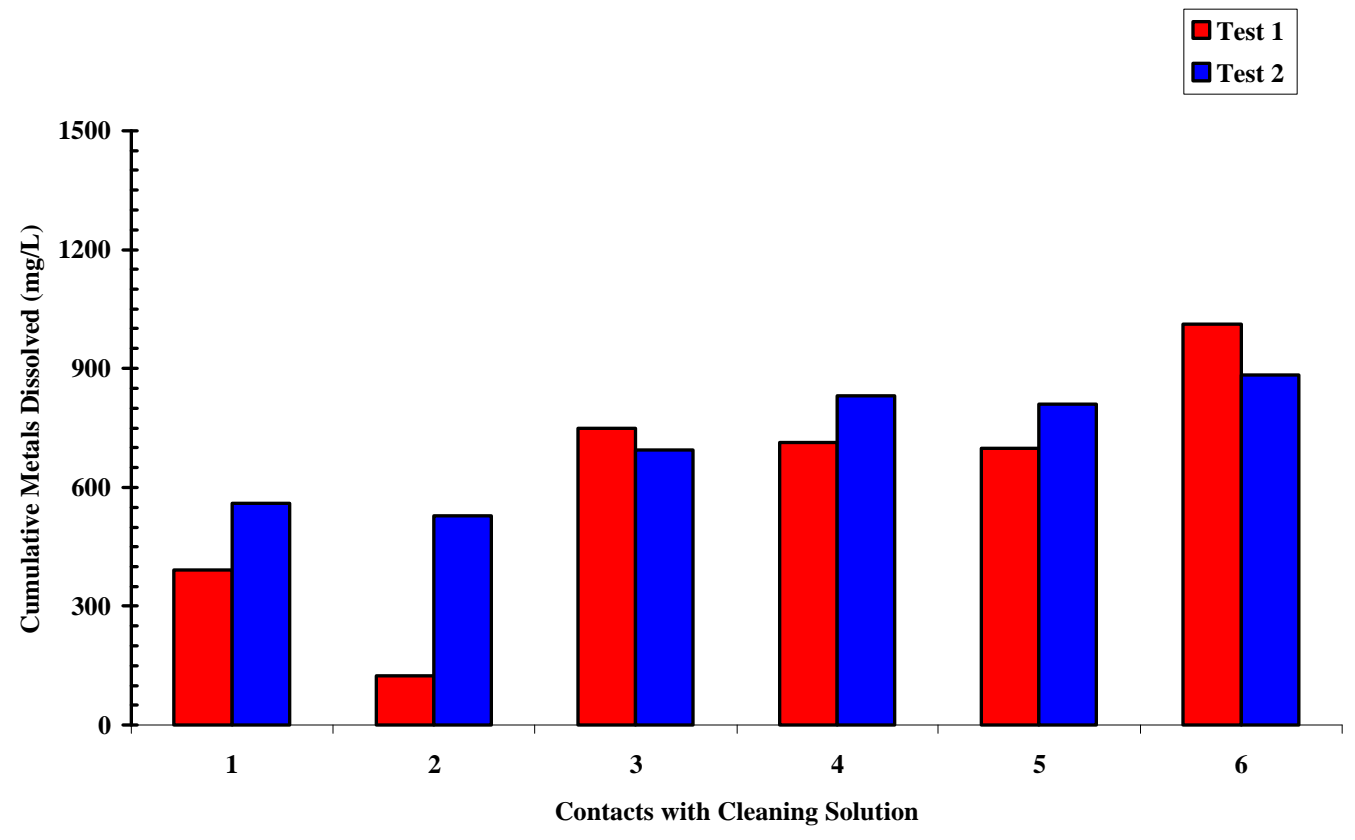

Figure 4.3.6 provides a plot of the total concentration of metals in the acid solution at each contact for the duplicate 50:1 tests with the HM sludge simulant after caustic leaching. Note that the HM sludge used in this test was not previously leached with $2 \mathrm{M} \mathrm{NaOH}$ solution. The first acid contact leached the largest quantity of metals from the simulated HM sludge. Subsequent contacts resulted in decreasing quantities of dissolved metals. This trend is similar to that measured for the simulated PUREX sludge (see Figure 4.3.2).

Note that the measured metals concentration did not agree particularly well for the $5^{\text {th }}$ and $6^{\text {th }}$ contacts. In one of the duplicates, the metals concentrations in the $5^{\text {th }}$ and $6^{\text {th }}$ tests rise sharply compared to the $4^{\text {th }}$ contact result. We do not have an explanation for the wide variance in the concentrations for these contacts. 


\section{Figure 4.3.6 Total Concentrations of Dissolved Metals upon Contact of Simulated HM Sludge with 50:1 Ratio of Oxalic/Citric Acid}

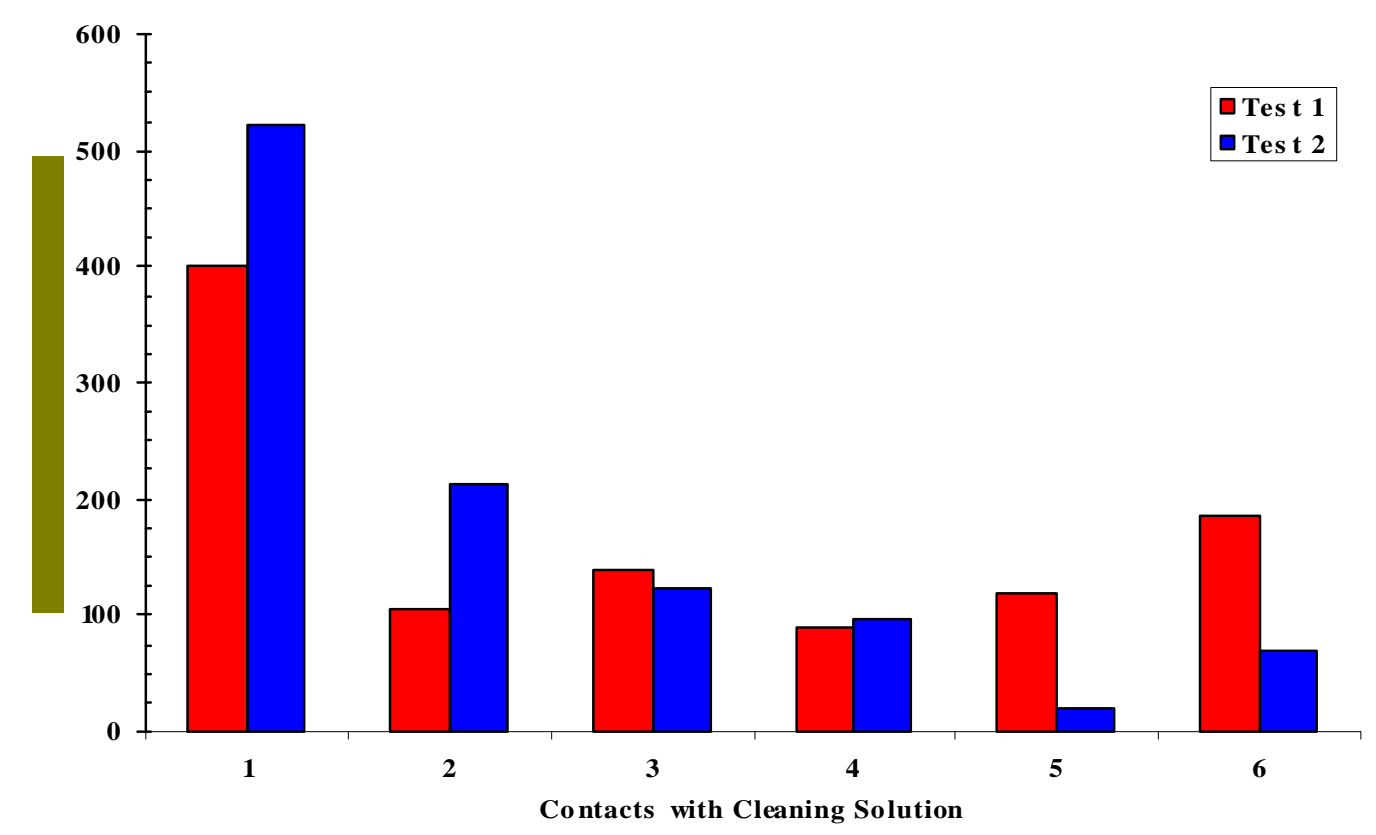

\subsection{Test Set \#2 Results with Simulated Sludges}

Tests carried out in this set featured both the oxalic/citric acid solutions previously discussed and a $4.0 \mathrm{wt} \%$ oxalic acid solution. After mixing the acid solution and the sludge, we adjusted the $\mathrm{pH}$ to 4.2 with a $2 \mathrm{M}$ sodium hydroxide solution. Tables 4.4.1 and 4.4.2 present the quantities of metals dissolved from the simulated PUREX sludge with the two acid solutions at a 2:1 (v/w) ratio of acid to sludge.

Through the first six contacts with the oxalic/citric acid mixture, the metals dissolution remained relatively constant. With the seventh contact, the quantities of dissolved aluminum and iron increased significantly. We observed a similar trend for the tests with 4 wt $\%$ oxalic acid solution with smaller increases aluminum and iron dissolution in the $6^{\text {th }}$ contact. In contrast to the oxalic/citric acid mixture, manganese dissolution showed a very large increase in the $6^{\text {th }}$ contact with $4 \mathrm{wt} \%$ oxalic acid. In general, the quantity of metal dissolved was lower in the $4 \mathrm{wt} \%$ oxalic acid solution compared to the oxalic/citric acid mixture even though the oxalic acid concentration is a factor of 1.6 times greater than that of the oxalic/citric acid mixture.

The cumulative quantity of Mn dissolved was the same for both acid solutions. The cumulative total metal dissolved in the oxalic and citric mixture follows the expected trend $(\mathrm{Fe}>\mathrm{Al}>\mathrm{Ni}>\mathrm{Mn})$ based on the initial concentration of the metal in the PUREX sludge and the stability constants for metal oxalate complexes. ${ }^{8}$ 
Table 4.4.1 Dissolution of PUREX Sludge with Oxalic/Citric Solution at a 2:1 (v/w) Acid to Sludge Ratio

\begin{tabular}{|c|c|c|c|c|c|c|}
\hline Test \# & $\begin{array}{c}\text { Contacts } \\
\text { with Acid } \\
\text { Solution }\end{array}$ & $\begin{array}{c}\text { Acid to } \\
\text { Sludge } \\
\text { Ratio }\end{array}$ & $\begin{array}{c}\text { Al } \\
\text { Dissolved } \\
\text { (Wt \%) }\end{array}$ & $\begin{array}{c}\text { Fe } \\
\text { Dissolved } \\
(\text { Wt \%) }\end{array}$ & $\begin{array}{c}\text { Mn } \\
\text { Dissolved } \\
\text { (Wt \%) }\end{array}$ & $\begin{array}{c}\text { Ni } \\
\text { Dissolved } \\
\text { (Wt \%) }\end{array}$ \\
\hline & $1^{\text {st }}$ & $2: 1$ & 6.39 & 3.25 & 6.65 & 4.13 \\
2 & $2^{\text {nd }}$ & $2: 1$ & 8.09 & 7.01 & 8.24 & 9.06 \\
3 & $3^{\text {rd }}$ & $2: 1$ & 12.7 & 14.0 & 6.70 & 15.5 \\
4 & $4^{\text {th }}$ & $2: 1$ & 9.27 & 7.76 & 6.37 & 11.8 \\
5 & $5^{\text {th }}$ & $2: 1$ & 11.0 & 11.2 & 8.16 & 12.8 \\
6 & $6^{\text {th }}$ & $2: 1$ & 13.0 & 11.2 & 10.0 & 10.3 \\
7 & $7^{\text {th }}$ & $2: 1$ & 23.2 & 29.9 & 6.28 & 10.1 \\
Cumulative & 7 & $2: 1$ & 83.8 & 84.6 & 52.4 & 73.7 \\
\hline
\end{tabular}

Table 4.4.2 Dissolution of PUREX Sludge with Oxalic Acid at a 2:1 (v/w) Acid to Sludge Ratio

\begin{tabular}{|c|c|c|c|c|c|c|}
\hline Test \# & $\begin{array}{c}\text { Contacts } \\
\text { with Acid } \\
\text { Solution }\end{array}$ & $\begin{array}{c}\text { Acid to } \\
\text { Sludge } \\
\text { Ratio }\end{array}$ & $\begin{array}{c}\mathrm{Al} \\
\text { Dissolved } \\
\text { (Wt \%) }\end{array}$ & $\begin{array}{c}\mathrm{Fe} \\
\text { Dissolved } \\
\text { (Wt \%) }\end{array}$ & $\begin{array}{c}\mathrm{Mn} \\
\text { Dissolved } \\
\text { (Wt \%) }\end{array}$ & $\begin{array}{c}\mathrm{Ni} \\
\text { Dissolved } \\
\text { (Wt \%) }\end{array}$ \\
\hline & & & & & & \\
1 & $1^{\text {st }}$ & $2: 1$ & 9.39 & 3.44 & 3.38 & 2.90 \\
2 & $2^{\text {nd }}$ & $2: 1$ & 5.83 & 3.83 & 7.48 & 6.97 \\
3 & $3^{\text {rd }}$ & $2: 1$ & 5.56 & 8.91 & 4.85 & 8.95 \\
4 & $4^{\text {th }}$ & $2: 1$ & 3.91 & 3.29 & 4.17 & 7.23 \\
5 & $5^{\text {th }}$ & $2: 1$ & 4.14 & 2.53 & 3.42 & 7.24 \\
6 & $6^{\text {th }}$ & $2: 1$ & 12.8 & 10.4 & 6.46 & 8.30 \\
7 & $7^{\text {th }}$ & $2: 1$ & 16.5 & 18.0 & 22.0 & 1.72 \\
Cumulative & 7 & $2: 1$ & 58.1 & 50.4 & 51.7 & 43.3 \\
\hline
\end{tabular}

Tables 4.4.3 and 4.4.4 present the results for contacts of the simulated PUREX sludge with 50:1 ratio of the oxalic/citric acid mixture and the 4 wt \% oxalic acid solution, respectively. The results indicated essentially complete dissolution of $\mathrm{Mn}$ and $\mathrm{Ni}$ in the first contact with either acid solution. Also, almost all of the iron dissolved in the $1^{\text {st }}$ contact with the oxalic/citric acid mixture compared to about $80 \%$ dissolution in oxalic acid. This result suggests that the oxalic/citric acid mixture is more efficient (i.e., degree of sludge dissolved per quantity of acid added) in the dissolution of iron than $4 \mathrm{wt} \%$ oxalic acid.

Dissolution of $\mathrm{Al}$ continued in the $2^{\text {nd }}$ and later contacts with oxalic acid tests until complete dissolution of the aluminum occurred after the $4^{\text {th }}$ contact. We were unable to measure $\mathrm{Al}$ dissolution after the $1^{\text {st }}$ contact with the oxalic/citric acid mixture. Note that we could not 
determine the extent of nickel dissolution after the first contact due to contamination from nickel in the stainless steel vessels used in the preparing the samples for analysis.

Table 4.4.3 Dissolution of PUREX Sludge with Oxalic/Citric Solution at a 50:1 (v/w) Acid to Sludge Ratio

\begin{tabular}{|c|c|c|c|c|c|c|}
\hline Test \# & $\begin{array}{c}\text { Contacts } \\
\text { with Acid } \\
\text { Solution }\end{array}$ & $\begin{array}{c}\text { Acid to } \\
\text { Sludge } \\
\text { Ratio }\end{array}$ & $\begin{array}{c}\mathrm{Al} \\
\text { Dissolved } \\
(\mathrm{Wt} \%)\end{array}$ & $\begin{array}{c}\mathrm{Fe} \\
\text { Dissolved } \\
(\mathrm{Wt} \%) \\
\end{array}$ & $\begin{array}{c}\mathrm{Mn} \\
\text { Dissolved } \\
(\mathrm{Wt} \%) \\
\end{array}$ & $\begin{array}{c}\mathrm{Ni} \\
\text { Dissolved } \\
(\mathrm{Wt} \%) \\
\end{array}$ \\
\hline 1 & $1^{\mathrm{st}}$ & $50: 1$ & 79.2 & 95.1 & 104 & 93.8 \\
\hline 2 & $2^{\text {nd }}$ & $50: 1$ & bql & bql & bql & $\mathrm{a}$ \\
\hline 3 & $3^{\text {rd }}$ & $50: 1$ & bql & bql & bql & $\mathrm{a}$ \\
\hline 4 & $4^{\text {th }}$ & $50: 1$ & bql & bql & bql & $\mathrm{a}$ \\
\hline 5 & $5^{\text {th }}$ & $50: 1$ & bql & bql & bql & $\mathrm{a}$ \\
\hline 6 & $6^{\text {th }}$ & $50: 1$ & bql & bql & bql & $\mathrm{a}$ \\
\hline 7 & $7^{\text {th }}$ & $50: 1$ & bql & bql & bql & $\mathrm{a}$ \\
\hline Cumulative & 7 & $50: 1$ & 79.2 & 99.5 & 104 & $\mathrm{a}$ \\
\hline
\end{tabular}

Table 4.4.4 Dissolution of PUREX Sludge with Oxalic Acid at a 50:1 (v/w) Acid to Sludge Ratio

\begin{tabular}{|c|c|c|c|c|c|c|}
\hline Test \# & $\begin{array}{c}\text { Contacts } \\
\text { with Acid } \\
\text { Solution } \\
\end{array}$ & $\begin{array}{c}\text { Acid to } \\
\text { Sludge } \\
\text { Ratio } \\
\end{array}$ & $\begin{array}{c}\mathrm{Al} \\
\text { Dissolved } \\
(\mathrm{Wt} \%) \\
\end{array}$ & $\begin{array}{c}\mathrm{Fe} \\
\text { Dissolved } \\
(\mathrm{Wt} \%) \\
\end{array}$ & $\begin{array}{c}\text { Mn } \\
\text { Dissolved } \\
(\mathrm{Wt} \%) \\
\end{array}$ & $\begin{array}{c}\mathrm{Ni} \\
\text { Dissolved } \\
(\mathrm{Wt} \%) \\
\end{array}$ \\
\hline 1 & $1^{\mathrm{st}}$ & $50: 1$ & 69.2 & 79.8 & 99.1 & 95.3 \\
\hline 2 & $2^{\text {nd }}$ & $50: 1$ & 17.5 & 5.83 & bql & $\mathrm{a}$ \\
\hline 3 & $3^{\text {rd }}$ & $50: 1$ & 23.2 & 10.7 & bql & $\mathrm{a}$ \\
\hline 4 & $4^{\text {th }}$ & $50: 1$ & 6.53 & 1.40 & bql & $\mathrm{a}$ \\
\hline 5 & $5^{\text {th }}$ & $50: 1$ & bql & 0.87 & bql & $a$ \\
\hline 6 & $6^{\text {th }}$ & $50: 1$ & bql & 3.56 & bql & $\mathrm{a}$ \\
\hline 7 & $7^{\text {th }}$ & $50: 1$ & bql & 2.76 & bql & $\mathrm{a}$ \\
\hline Cumulative & 7 & $50: 1$ & 116 & 96.0 & 99.1 & $\mathrm{a}$ \\
\hline
\end{tabular}

Tables 4.4.5 and 4.4.6 provide the results for the contacts of the simulated HM sludge at 2:1 volume ratios of sludge to acid for the oxalic/citric acid mixture and $4 \mathrm{wt} \%$ oxalic acid mixture, respectively. The largest fraction of $\mathrm{Al}$ dissolved in the $1^{\text {st }}$ contact. Overall, the metals dissolution followed the order $\mathrm{Ni}>\mathrm{Mn}>\mathrm{Fe}>\mathrm{Al}$ in the oxalic/citric acid mixture. In oxalic acid, the metals dissolution followed the order $\mathrm{Ni}>\mathrm{Mn}>\mathrm{Al}, \mathrm{Fe}$. Thus, the observed 
cumulative dissolution follow in reverse order to that in the simulated $\mathrm{HM}$ sludge, $\mathrm{Al}>\mathrm{Fe}>$ $\mathrm{Mn}>\mathrm{Ni}$.

Table 4.4.5 Dissolution of HM Sludge with Oxalic/Citric Acid Mixture at a 2:1 (v/w) Acid to Sludge Ratio

\begin{tabular}{|c|c|c|c|c|c|c|}
\hline Test \# & $\begin{array}{c}\text { Contacts } \\
\text { with Acid } \\
\text { Solution }\end{array}$ & $\begin{array}{c}\text { Acid to } \\
\text { Sludge } \\
\text { Ratio }\end{array}$ & $\begin{array}{c}\text { Al } \\
\text { Dissolved } \\
\text { (Wt \%) }\end{array}$ & $\begin{array}{c}\text { Fe } \\
\text { Dissolved } \\
(\mathrm{Wt} \%)\end{array}$ & $\begin{array}{c}\text { Mn } \\
\text { Dissolved } \\
\text { (Wt \%) }\end{array}$ & $\begin{array}{c}\text { Ni } \\
\text { Dissolved } \\
\text { (Wt \%) }\end{array}$ \\
\hline & $1^{\text {st }}$ & $2: 1$ & 7.03 & 1.19 & 1.50 & 5.42 \\
2 & $2^{\text {nd }}$ & $2: 1$ & 2.84 & 13.32 & 22.4 & 18.4 \\
3 & $3^{\text {rd }}$ & $2: 1$ & 6.44 & 12.4 & 10.5 & 19.6 \\
4 & $4^{\text {th }}$ & $2: 1$ & 0.92 & 7.85 & 10.1 & 17.2 \\
5 & $5^{\text {th }}$ & $2: 1$ & 1.01 & 4.07 & 4.03 & 6.14 \\
6 & $6^{\text {th }}$ & $2: 1$ & 0.83 & 0.83 & 0.53 & 3.40 \\
7 & $7^{\text {th }}$ & $2: 1$ & 0.32 & 0.25 & bql & 5.23 \\
Cumulative & 7 & $2: 1$ & 19.4 & 40.0 & 49.1 & 75.4 \\
\hline
\end{tabular}

Table 4.4.6 Dissolution of HM Sludge with Oxalic Acid at a 2:1 (v/w) Acid to Sludge Ratio

\begin{tabular}{|c|c|c|c|c|c|c|}
\hline Test \# & $\begin{array}{c}\text { Contacts } \\
\text { With Acid } \\
\text { Solution }\end{array}$ & $\begin{array}{c}\text { Acid to } \\
\text { Sludge } \\
\text { Ratio }\end{array}$ & $\begin{array}{c}\text { Al } \\
\text { Dissolved } \\
\text { (Wt \%) }\end{array}$ & $\begin{array}{c}\text { Fe } \\
\text { Dissolved } \\
\text { (Wt \%) }\end{array}$ & $\begin{array}{c}\text { Mn } \\
\text { Dissolved } \\
\text { (Wt \%) }\end{array}$ & $\begin{array}{c}\text { Ni } \\
\text { Dissolved } \\
\text { (Wt \%) }\end{array}$ \\
\hline & $1^{\text {st }}$ & $2: 1$ & 0.66 & 1.06 & 8.88 & 10.8 \\
2 & $2^{\text {nd }}$ & $2: 1$ & 7.04 & 6.60 & 17.4 & 9.21 \\
3 & $3^{\text {rd }}$ & $2: 1$ & 12.2 & 12.0 & 16.4 & 20.6 \\
4 & $4^{\text {th }}$ & $2: 1$ & 3.07 & 1.84 & 6.53 & 20.7 \\
5 & $5^{\text {th }}$ & $2: 1$ & 3.77 & 5.23 & 2.08 & 11.6 \\
6 & $6^{\text {th }}$ & $2: 1$ & 1.09 & 0.90 & 0.7 & 3.61 \\
7 & $7^{\text {th }}$ & $2: 1$ & bql & bql & bql & bql \\
Cumulative & $7^{7}$ & $2: 1$ & 27.8 & 27.6 & 52.0 & 76.6 \\
\hline
\end{tabular}

Tables 4.4.7 and 4.4.8 provide the dissolution results for the simulated HM sludge at the 50:1 acid to sludge ratio for the oxalic/citric acid mixture and $4 \mathrm{wt} \%$ oxalic acid solutions, respectively. As measured in the tests with the simulated PUREX sludge with 50:1 acid to sludge contacts, metals dissolution is highest in the $1^{\text {st }}$ contact and decreases thereafter. In contrast to the results with the PUREX sludge, higher cumulative metals dissolution occurred with the 4 wt \% oxalic acid compared to the oxalic/citric acid mixture. Considering the cumulative metals dissolution of the simulated HM sludge, we conclude that 4 wt \% oxalic 
acid proved more efficient than the oxalic/citric acid mixture in this series of tests.

Table 4.4.7 Dissolution of HM Sludge with Oxalic/Citric Acid Mixture at a 50:1 (v/w) Acid to Sludge Ratio

\begin{tabular}{|c|c|c|c|c|c|c|}
\hline Test \# & $\begin{array}{c}\text { Contacts } \\
\text { with Acid } \\
\text { Solution }\end{array}$ & $\begin{array}{c}\text { Acid to } \\
\text { Sludge } \\
\text { Ratio }\end{array}$ & $\begin{array}{c}\mathrm{Al} \\
\text { Dissolved } \\
(\mathrm{Wt} \%) \\
\end{array}$ & $\begin{array}{c}\mathrm{Fe} \\
\text { Dissolved } \\
(\mathrm{Wt} \%)\end{array}$ & $\begin{array}{c}\mathrm{Mn} \\
\text { Dissolved } \\
(\mathrm{Wt} \%) \\
\end{array}$ & $\begin{array}{c}\mathrm{Ni} \\
\text { Dissolved } \\
(\mathrm{Wt} \%) \\
\end{array}$ \\
\hline 1 & $1^{\mathrm{st}}$ & $50: 1$ & 41.6 & 28.2 & 39.8 & 81.0 \\
\hline 2 & $2^{\text {nd }}$ & $50: 1$ & 9.86 & 29.4 & 12.6 & $\mathrm{a}$ \\
\hline 3 & $3^{\text {rd }}$ & $50: 1$ & 2.79 & 18.8 & 3.08 & $\mathrm{a}$ \\
\hline 4 & $4^{\text {th }}$ & $50: 1$ & 5.98 & 8.00 & bql & $\mathrm{a}$ \\
\hline 5 & $5^{\text {th }}$ & $50: 1$ & bql & bql & bql & $\mathrm{a}$ \\
\hline 6 & $6^{\text {th }}$ & $50: 1$ & bql & bql & bql & $\mathrm{a}$ \\
\hline 7 & $7^{\text {th }}$ & $50: 1$ & bql & bql & bql & $\mathrm{a}$ \\
\hline Cumulative & 7 & $50: 1$ & 60.2 & 84.4 & 56.0 & $\mathrm{a}$ \\
\hline
\end{tabular}

Table 4.4.8 Dissolution of HM Sludge with Oxalic Acid at a 50:1 (v/w) Acid to Sludge Ratio

\begin{tabular}{|c|c|c|c|c|c|c|}
\hline Test \# & $\begin{array}{c}\text { Contacts } \\
\text { with Acid } \\
\text { Solution }\end{array}$ & $\begin{array}{c}\text { Acid to } \\
\text { Sludge } \\
\text { Ratio }\end{array}$ & $\begin{array}{c}\mathrm{Al} \\
\text { Dissolved } \\
(\mathrm{Wt} \%) \\
\end{array}$ & $\begin{array}{c}\mathrm{Fe} \\
\text { Dissolved } \\
(\mathrm{Wt} \%)\end{array}$ & $\begin{array}{c}\mathrm{Mn} \\
\text { Dissolved } \\
(\mathrm{Wt} \%) \\
\end{array}$ & $\begin{array}{c}\mathrm{Ni} \\
\text { Dissolved } \\
(\mathrm{Wt} \%) \\
\end{array}$ \\
\hline 1 & $1^{\text {st }}$ & $50: 1$ & 42.0 & 70.8 & 96.9 & 100 \\
\hline 2 & $2^{\text {nd }}$ & $50: 1$ & 8.64 & 5.83 & 1.46 & $\mathrm{a}$ \\
\hline 3 & $3^{\text {rd }}$ & $50: 1$ & 5.66 & 10.7 & 0.33 & $\mathrm{a}$ \\
\hline 4 & $4^{\text {th }}$ & $50: 1$ & 6.53 & 1.40 & bql & $\mathrm{a}$ \\
\hline 5 & $5^{\text {th }}$ & $50: 1$ & 5.19 & 0.87 & bql & $\mathrm{a}$ \\
\hline 6 & $6^{\text {th }}$ & 50:1 & 5.86 & 3.56 & bql & $\mathrm{a}$ \\
\hline 7 & $7^{\text {th }}$ & $50: 1$ & 6.19 & 2.76 & bql & $\mathrm{a}$ \\
\hline Cumulative & 7 & $50: 1$ & 80.1 & 96.0 & 98.6 & $\mathrm{a}$ \\
\hline
\end{tabular}

Tables 4.4.9 and 4.4.10 provide the normalized cumulative quantities of metals dissolved on a molar basis in the 2:1 and 50:1 tests with the $4 \mathrm{wt} \%$ oxalic solution and the oxalic/citric acid mixture. Nickel serves as the normalizing metal since it is the least abundant metal among the four chief metals, $\mathrm{Al}, \mathrm{Fe}, \mathrm{Mn}$ and Ni. The normalized cumulative quantities of dissolved metals follow the order, $\mathrm{Fe}>\mathrm{Mn}>\mathrm{Al}>\mathrm{Ni}$ at both acid to sludge ratios $(2: 1$ and 50:1) with the PUREX sludge and $\mathrm{Al}>\mathrm{Fe}>\mathrm{Mn}>\mathrm{Ni}$ for the HM sludge. This order follows the same order of metal concentrations in both of the simulated sludges (see Table 4.1.1). 
The cumulative molar ratios for $\mathrm{Al}, \mathrm{Fe}$ and $\mathrm{Mn}$ from the dissolution of the PUREX sludge are similar to those in the original sludge simulant. This suggests that over the course of seven contacts the metals in this simulated sludge dissolve in proportion to the respective concentrations in the sludge solids. The higher mole ratio for dissolved $\mathrm{Mn}$ in the tests with the oxalic/citric acid mixture compared to oxalic acid suggests that the addition of citric acid provides additional complexation of the manganese resulting in the greater dissolution compared to an acid solution that contains only oxalic acid.

Table 4.2.3 Normalized Cumulative Quantity of Dissolved Metals in Simulated PUREX Sludge*

\begin{tabular}{|c|c|c|c|c|c|}
\hline \multirow[b]{3}{*}{ Element } & \multicolumn{5}{|c|}{$\begin{array}{c}\text { Simulated } \\
\text { PUREX Sludge } \\
\text { (mole/mole Ni) }\end{array}$} \\
\hline & & $\mathbf{O A}$ & OA/CA & $\mathbf{O A}$ & OA/CA \\
\hline & Sample & $2: 1$ & $\underline{2: 1}$ & $\underline{50: 1}$ & 50:1 \\
\hline $\mathrm{Al}$ & 2.33 & 2.65 & 3.12 & 1.97 & 1.69 \\
\hline $\mathrm{Fe}$ & 9.08 & 10.4 & 10.6 & 9.20 & 9.20 \\
\hline Mn & 4.53 & 3.23 & 5.42 & 5.03 & 5.03 \\
\hline $\mathrm{Ni}$ & 1.00 & 1.00 & 1.00 & 1.00 & 1.00 \\
\hline
\end{tabular}

Table 4.2.4 Normalized Cumulative Quantity of Dissolved Metals in Simulated HM Sludge*

\begin{tabular}{|c|c|c|c|c|c|}
\hline \multirow[b]{3}{*}{$\underline{\text { Element }}$} & \multicolumn{5}{|c|}{$\begin{array}{c}\text { Simulated HM } \\
\text { Sludge } \\
(\mathrm{mole} / \mathrm{mole} \mathrm{Ni})\end{array}$} \\
\hline & & $\mathbf{O A}$ & OA/CA & $\mathbf{O A}$ & OA/CA \\
\hline & Sample & $\underline{2: 1}$ & $\underline{2: 1}$ & $\underline{50: 1}$ & 50:1 \\
\hline $\mathrm{Al}$ & 54.0 & 13.8 & 19.5 & 27.6 & 22.5 \\
\hline $\mathrm{Fe}$ & 11.2 & 5.93 & 4.03 & 3.89 & 7.91 \\
\hline $\mathrm{Mn}$ & 5.83 & 3.83 & 3.96 & 2.86 & 5.65 \\
\hline $\mathrm{Ni}$ & 1.00 & 1.00 & 1.00 & 1.00 & 1.00 \\
\hline
\end{tabular}




\subsection{Results with Radioactive HLW Sludge Samples}

The final set of tests evaluated the dissolution of archived sludge samples from SRS Tanks $8 \mathrm{~F}$ and $12 \mathrm{H}$. The Tank $8 \mathrm{~F}$ sample is a sludge produced from PUREX processing, whereas the $12 \mathrm{H}$ sample is a sludge produced from $\mathrm{HM}$ processing. These samples have been stored for a number of years in a dry state. Because of the dry storage, these materials may present more of a challenge for dissolution than typical sludge materials that are maintained in a wetted condition.

We performed duplicate tests with each sludge sample (Tank 8F and Tank 12H) and each acid solution (4 wt \% oxalic acid and oxalic/citric acid mixture). We contacted each sample a total of four times with the acid solution. However, due to budget limitations we analyzed only the solutions isolated from the first 2 contacts. Table 4.5 .1 provides a summary of the average calculated base and acid equivalents and the ratio of acid:base in each of the dissolution tests. We calculated the total base equivalents from the elemental composition provided in Table 4.2.1 assuming aluminum and iron contribute three base equivalents per mole, manganese, nickel and uranium contribute two based equivalents per mole, plutonium contributes four base equivalents per mole and that sodium contributes one base equivalent per mole. The acid equivalent is calculated for a single contact.

For the 2:1 tests, the equivalents of acid added for the first contact is less than $7 \%$ of the calculated total base equivalents. For the 50:1 tests the acid equivalents is much higher ranging from $16 \%$ to $160 \%$. On average the amount of acid added per contact with the oxalic acid solution is 4.4 times greater than the oxalic/citric acid mixture and 2.3 times greater for the PUREX tests than the HM tests.

Tables 4.5.2 and 4.5.3 provide the total quantity of elements ( $\mathrm{Al}, \mathrm{Fe}, \mathrm{Mn}, \mathrm{Ni}, \mathrm{Na}, \mathrm{U}$ and $\mathrm{Pu}$ ) dissolved for the HM and PUREX sludge samples calculated on a weight percent and mole percent basis, respectively. Dissolution of the HM sludge sample proved low with both acids and at both acid:sludge ratios. We attribute the overall low dissolution of the sample to the high aluminum content $(35.1 \mathrm{wt} \%)$ in the HM sludge. Previous studies reported that oxalic acid is not particularly effective in dissolving aluminum oxide phases. ${ }^{9,10}$

In general sludge dissolution proved higher with the mixed oxalic/citric acid solution than 4 wt $\%$ oxalic acid solution in spite of the lower total acid equivalents added. We attribute this trend to citrate serving as a more effective complexing agent and, thereby, solubilizing more metal ions than oxalate. We observed little difference (OA/CA mixture) or lower dissolution $(\mathrm{OA})$ in the quantity of sludge dissolved at the two different acid:sludge ratios. One would expect more dissolution to occur at the higher 50:1 ratio compared to the 2:1 ratio. This result suggests the bulk of the elements in the HM sludge sample are present in more recalcitrant phases that are not effectively dissolved by either oxalic or oxalic/citric acid solutions. 


\section{Table 4.5.1 Calculated Total Base and Total Acid Equivalents in Sludge Dissolution} Tests

\begin{tabular}{ccccc} 
& \multicolumn{5}{c}{$\begin{array}{c}\text { Total Base } \\
\text { Equivalents } \\
\text { (mmole) }\end{array}$} & & \\
& HM & HM & PUREX & PUREX \\
Acid & $\mathbf{2 : 1}$ & $\mathbf{5 0 : 1}$ & $\mathbf{2 : 1}$ & $\mathbf{5 0 : 1}$ \\
\hline OA & 450 & 60 & 210 & 17 \\
OA/CA & 420 & 59 & 210 & 18
\end{tabular}

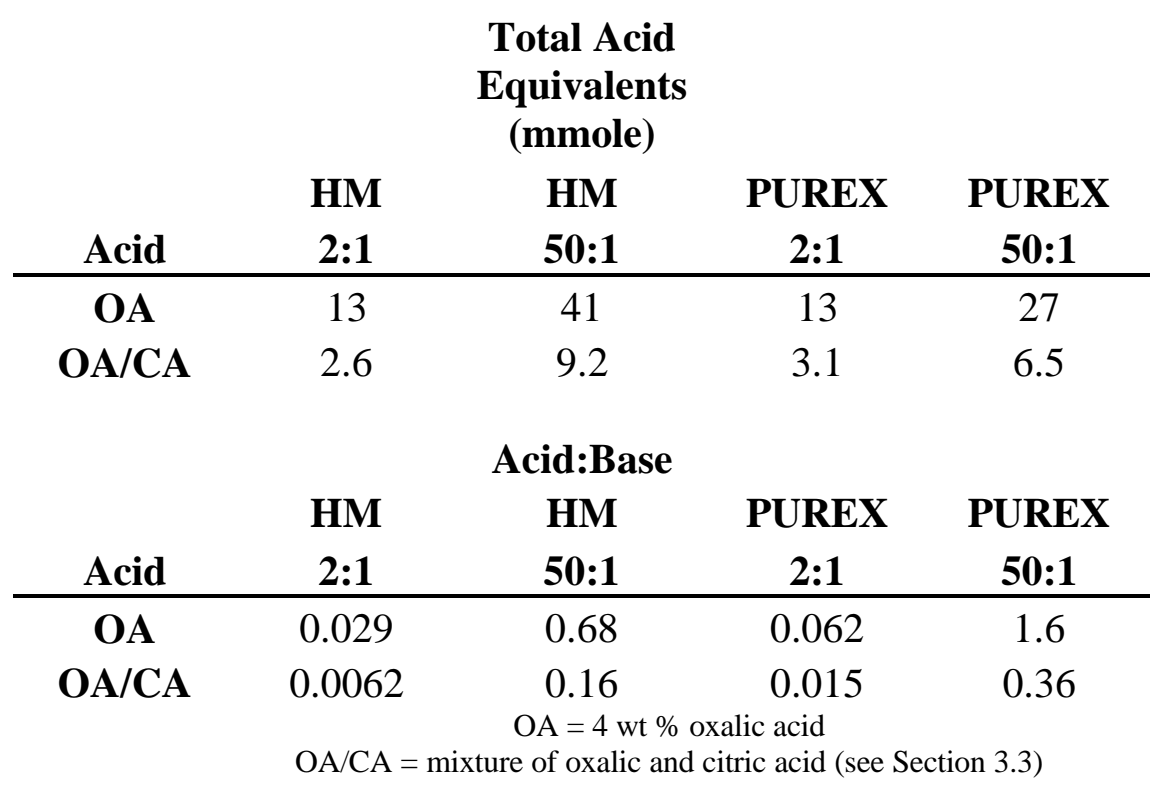

Dissolution of the PUREX sludge sample proved much higher than that measured with the HM sludge sample. These results are consistent with the solubilities of the primary components in the respective sludges (aluminum in the HM sludge and iron in the PUREX sludge). Iron oxalate exhibits a higher solubility than aluminum oxalate in acidic solutions. The bulk of the PUREX sludge dissolution occurred in the first contact. At the 2:1 ratio about $70 \%$ of sludge that dissolved did so in the first contact. At the 50:1 ratio this increased to more than $95 \%$. There was no statistically significant difference in the quantity of sludge dissolved with oxalic acid or the oxalic/citric acid mixture. In contrast to the HM sample, the PUREX sample contains a high concentration of uranium $(14.2 \mathrm{wt} \%)$. The uranium present in this sample appears to readily dissolve in either acid.

With the exception of the $2: 1$ contact with the HM sludge sample, the dissolution of the sludge solids was very similar between the $4 \mathrm{wt} \%$ oxalic solution $(0.4 \mathrm{M})$ and the more dilute mixed acid solutions of oxalic acid $(0.056-0.167 \mathrm{M})$ and citric acid $(0.024-$ $0.071 \mathrm{M})$. This finding suggests that the combination of oxalic and citric acids provides a 
more efficient dissolution media for both HM and PUREX sludges than that of oxalic acid alone. The more efficient dissolution is attributed to increased complexation due to citrate since the total available acid concentration in the oxalic citric acid solutions ranged from $0.184 \mathrm{M}$ (HM test) to $0.547 \mathrm{M}$ (PUREX test) in the mixed acid solutions and $0.800 \mathrm{M}$ for the oxalic acid solution. Both oxalate and citrate form metal complexes with a variety of metals including aluminum, iron, manganese and nickel. Increased complexation of these metals is consistent with the higher stability constants reported in the literature for citrate complexes compared to those of oxalate. ${ }^{8}$

Tables 4.5.4 and 4.5.5 provides the individual and cumulative normalized mole quantities of sludge for Al, Fe, Mn, Ni, Na and U (PUREX only) for the Tank $12 \mathrm{H}$ and Tank 7F samples, respectively. We also include the normalized mole quantities in the dried sludge samples before contact with the acid solutions. We chose to normalize with nickel since this element proved the lowest of the elements in both the HM and PUREX sludge samples. Also, nickel dissolution was generally less than that of the other elements. Plutonium is a minor component in both sludge samples on a mass basis and, thus, we omitted this element from this calculation (discussed later). Comparison of the normalized concentrations in the acid dissolutions to that in the original sludge sample provides an indication of the propensity of that metal to dissolve relative to the other metals.

In oxalic acid we observed greater dissolution of $\mathrm{Al}, \mathrm{Fe}, \mathrm{Mn}$ and $\mathrm{Na}$ than that of $\mathrm{Ni}$. At both acid:sludge ratios $\mathrm{Na}$ dissolution proved much greater relative to $\mathrm{Ni}$ than any of the other metals (see Table 4.5.4). Note however, that the ratio of dissolved $\mathrm{Al}$ : Ni is much lower than that in the original sample. The behavior of $\mathrm{Al}$ is consistent with previous studies that indicate low dissolution of $\mathrm{Al}$ in oxalic acid. ${ }^{9,10}$

Greater $\mathrm{Na}$ dissolution occurred even in the presence of 14 times more $\mathrm{Al}$ than $\mathrm{Na}$. We attribute the relatively high $\mathrm{Na}$ dissolution to the dissolution of dried sodium salts in the samples. Overall much greater dissolution of metals occurred at the higher acid:sludge ratio. Note that ratios of $\mathrm{Fe}, \mathrm{Mn}$ and $\mathrm{Na}$ are much lower in the acid solution from the second contact compared to the first contact for the 50:1 tests. We believe this finding reflects depletion of these metals in the remaining solids after the first contact.

In the oxalic/citric acids mixture we observed that the normalized ratios of Fe and $\mathrm{Mn}$ are similar to that in the original sludge sample. The ratios of Fe:Ni in the 2:1 tests are lower than that in the original sludge sample. We attribute these results to similar propensity of the acid to dissolve these elements principally due to the presence of citrate that forms strong complexes with these metals. ${ }^{8}$ The somewhat reduced dissolution of $\mathrm{Fe}$ in the 2:1 tests may reflect a lower acid content compared to that in the 50:1 tests (see Table 4.5.1). We observed high Na:Ni ratios in the acid solutions. As in the case with oxalic acid, we believe the high $\mathrm{Na}$ :Ni ratios reflect dissolution of sodium salts.

We observed relatively low dissolution of $\mathrm{Al}, \mathrm{Fe}, \mathrm{Mn}$ in the first contacts of the PUREX sludge sample with either oxalic or the oxalic/citric acids mixture at the 2:1 ratio (see Table 4.5.5). At the 50:1 ratios, $\mathrm{Al}, \mathrm{Fe}$ and $\mathrm{Mn}$ exhibit much higher normalized values indicating 
relatively greater dissolution of these elements compared to nickel. The reduced dissolution of $\mathrm{Al}, \mathrm{Fe}$ and $\mathrm{Mn}$ in the 2:1 tests may reflect a lower acid content compared to that in the 50:1 tests (see Table 4.5.1).

As in the case with the HM sludge sample, we observed high Na:Ni ratios in all of the dissolution tests. In the 50:1 tests, the Na:Ni ratios in the second contacts of the 50:1 tests with either acid are much lower than those measured in the first contact. These findings reflect the dissolution of sodium salts in the dried sludge solids.

The PUREX sludge sample contains almost equivalent quantities of uranium and nickel on a mole basis. With the exception of the 50:1 tests with the oxalic acid and the oxalic/citric acids mixture, the ratios of $\mathrm{U}: \mathrm{Ni}$ in the acid solutions reflect greater relative dissolution of the uranium. The U:Ni ratios for the first contacts in both acid solutions and both acid:sludge ratios are similar. Thus, we conclude that the uranium in this sample readily dissolves in both acid solutions. This is not unexpected since uranium forms a variety of stable complexes with oxalate under acidic conditions. ${ }^{8,11}$

Uranium and plutonium dissolution in the acid solution is important for nuclear criticality safety. Criticality safety is assured in the high level waste tanks due to the low concentration of fissile isotopes and high concentration of neutron poisons in the sludge solids. Note that in PUREX sludges, depleted uranium (DU) serves as a neutron poison in addition to the other metals (e.g., Fe). Ideally, dissolution of uranium and plutonium occurs in the same molar ratios as that of the neutron poisons to prevent concentration of fissile isotopes either in the acid solutions or in the residual sludge solids. However, the neutron poisons and fissile isotopes (chiefly ${ }^{233} \mathrm{U},{ }^{235} \mathrm{U}$ and ${ }^{239} \mathrm{Pu}$ ) exhibit different solubilities. Consequently the ratios of neutron poisons to fissile isotopes will change upon dissolution. 
Table 4.5.2 Quantity of Dissolved Sludge Solids

\section{Quantity Dissolved (wt \%)}

HM

\section{PUREX}

\begin{tabular}{c|c|c|c|c|c|c|c|c|}
\multicolumn{2}{c}{} & \multicolumn{2}{c}{ Oxalic } & \multicolumn{2}{c}{ Oxalic/Citric } & \multicolumn{2}{c}{ Oxalic } & \multicolumn{2}{c}{ Oxalic/Citric } \\
Contact & $\mathbf{2 : 1}$ & $\mathbf{5 0 : 1}$ & $\mathbf{2 : 1}$ & $\mathbf{5 0 : 1}$ & 19 & $66 \pm 6.2$ & 20 & $59 \pm 12$ \\
\hline $\mathbf{1}^{\text {st }}$ & $4.9 \pm 0.19$ & 12 & $2.6 \pm 0.14$ & 13 & 19 & \\
\hline $2^{\text {nd }}$ & $3.3 \pm 0.26$ & $1.6 \pm 0.42$ & $1.5 \pm 0.14$ & $3.0 \pm 1.9$ & 10 & $2.6 \pm 1.2$ & 10 & $1.8 \pm 1.9$ \\
\hline Total & $8.2 \pm 0.45$ & 14 & $4.1 \pm 0.28$ & 16 & 29 & $69 \pm 7.4$ & 30 & $61 \pm 14$ \\
\hline
\end{tabular}

Quantity of solids dissolved calculated based on the measured amounts of Al, Fe, Mn, Ni $\mathrm{Na}, \mathrm{U}$ and $\mathrm{Pu}$ in the archived dry sludge sample and in the acid solution after contacting with the sludge sample. Values are the average and single standard deviation for duplicate tests. Results without a standard deviation reflect only a single measurement. 
Table 4.5.3 Quantity of Dissolved Sludge Solids

\section{Quantity Dissolved (mole \%)}

HM

\section{PUREX}

\begin{tabular}{|c|c|c|c|c|c|c|c|c|}
\hline \multirow[b]{2}{*}{ Contact } & \multicolumn{2}{|c|}{ Oxalic } & \multicolumn{2}{|c|}{ Oxalic/Citric } & \multicolumn{2}{|c|}{ Oxalic } & \multicolumn{2}{|c|}{ Oxalic/Citric } \\
\hline & $2: 1$ & $50: 1$ & $2: 1$ & $50: 1$ & 2:1 & 50:1 & $2: 1$ & $50: 1$ \\
\hline $1^{\text {st }}$ & $5.8 \pm 0.22$ & $3.2 \pm 0.19$ & $11 \pm 0.35$ & 11 & 32 & $74 \pm 5.9$ & 35 & $67 \pm 12$ \\
\hline $2^{\text {nd }}$ & $2.9 \pm 0.17$ & $1.7 \pm 0.17$ & $1.5 \pm 0.41$ & $2.7 \pm 2.0$ & 10 & $2.6 \pm 1.3$ & 9.7 & $2.1 \pm 1.6$ \\
\hline Total & $8.7 \pm 0.39$ & $4.9 \pm 0.36$ & $12 \pm 0.76$ & 14 & 42 & $77 \pm 7.2$ & 45 & $70 \pm 14$ \\
\hline
\end{tabular}

Quantity of solids dissolved calculated based on the measured amounts of Al, Fe, Mn, Ni $\mathrm{Na}, \mathrm{U}$ and $\mathrm{Pu}$ in the archived dry sludge sample and in the acid solution after contacting with the sludge sample. Values are the average and single standard deviation for duplicate tests. Results without a standard deviation reflect only a single measurement. 
Table 4.5.4 Normalized Quantities of Dissolved Metals in Tank 12H HM Sludge

\section{Normalized Mole Ratios (mmole/mmole Ni)}

\begin{tabular}{|c|c|c|}
\hline$\underline{\text { Element }}$ & Sample & $\underline{2: 1}$ \\
\hline $\mathrm{Al}$ & 168 & $10 \pm 9.9$ \\
\hline $\mathrm{Fe}$ & 9.27 & $20 \pm 1.5$ \\
\hline $\mathrm{Mn}$ & 4.75 & $8.5 \pm 0.17$ \\
\hline $\mathrm{Na}$ & 11.8 & $830+6.2$ \\
\hline $\mathrm{Ni}$ & 1.0 & $1 . \overline{0}$ \\
\hline $\mathrm{Al}$ & 168 & $110 \pm 48$ \\
\hline $\mathrm{Fe}$ & 9.27 & $88+28$ \\
\hline $\mathrm{Mn}$ & 4.75 & $60 \pm 18$ \\
\hline $\mathrm{Na}$ & 11.8 & $280 \pm 110$ \\
\hline $\mathrm{Ni}$ & 1.0 & 1.0 \\
\hline $\mathrm{Al}$ & 168 & $110 \pm 27$ \\
\hline $\mathrm{Fe}$ & 9.27 & $51 \pm 5.8$ \\
\hline $\mathrm{Mn}$ & 4.75 & $32 \pm 3.6$ \\
\hline $\mathrm{Na}$ & 11.8 & $560 \pm 110$ \\
\hline $\mathrm{Ni}$ & 1.0 & 1.0 \\
\hline
\end{tabular}

Oxalic Acid

$$
\begin{gathered}
\underline{\mathbf{5 0 : 1}} \\
\text { First Contact } \\
350 \pm 150 \\
240 \pm 160 \\
130 \pm 81 \\
560 \pm 310 \\
1.0
\end{gathered}
$$

\section{Second Contact}

$$
\begin{gathered}
58 \pm 19 \\
6.9 \pm 1.4 \\
3.5 \pm 0.68 \\
11 \pm 0.78 \\
1.0 \\
\text { Cumulative } \\
150 \pm 25 \\
74 \pm 22 \\
41 \pm 10 \\
170 \pm 33 \\
1.0
\end{gathered}
$$

\section{Cumulative}

Oxalic/Citric Acids

$\underline{2: 1} \quad \underline{50: 1}$

$\begin{array}{cc}5.8 \pm 0.79 & 5.2 \pm 5.4 \\ 0.40 \pm 0.0090 & 4.6 \pm 0.31 \\ 2.6 \pm 0.89 & 6.7 \pm 1.7 \\ 500 \pm 78 & 29 \pm 17 \\ 1.0 & 1.0\end{array}$

$$
\begin{gathered}
13 \pm 2.5 \\
1.2 \pm 0.11 \\
4.4 \pm 0.57 \\
130 \pm 15 \\
1.0
\end{gathered}
$$

$$
\begin{gathered}
22 \pm 17 \\
8.50 .74 \\
2.9 \pm 0.037 \\
17 \pm 18 \\
1.0
\end{gathered}
$$

$$
\begin{gathered}
10 \pm 1.2 \\
0.90 \pm 0.087 \\
3.8 \pm 0.095 \\
260 \pm 9.6 \\
1.0
\end{gathered}
$$

$$
\begin{gathered}
9.4 \pm 0.22 \\
6.4 \pm 1.4 \\
5.2 \pm 2.8 \\
15 \pm 6.4 \\
1.0
\end{gathered}
$$


Table 4.5.5 Normalized Quantities of Dissolved Metals in Tank 8F PUREX Sludge

\begin{tabular}{|c|c|c|c|c|c|}
\hline \multirow[b]{2}{*}{$\underline{\text { Element }}$} & \multicolumn{5}{|c|}{ Normalized Mole Ratios (mmole/mmole Ni) } \\
\hline & $\underline{\text { Sample }}$ & $\underline{2: 1}$ & $\underline{50: 1}$ & $2: 1$ & 50:1 \\
\hline & & & First_Contact & & \\
\hline $\mathrm{Al}$ & 1.70 & 0.30 & $40+20$ & 0.74 & $59 \pm 3.4$ \\
\hline $\mathrm{Fe}$ & 6.11 & 0.10 & $106 \pm 36$ & 0.28 & $120 \pm 58$ \\
\hline $\mathrm{Mn}$ & 1.13 & 0.25 & $12 \pm 2.1$ & 0.73 & $22 \pm 3.7$ \\
\hline $\mathrm{Na}$ & 7.54 & 480 & $240 \pm 120$ & 1100 & $410 \pm 110$ \\
\hline $\mathrm{U}$ & 1.07 & 2300 & $32 \pm 0.14$ & 26 & $51 \pm 0.53$ \\
\hline $\mathrm{Ni}$ & 1.0 & 1.0 & 1.0 & 1.0 & 1.0 \\
\hline & & & Second Contac & & \\
\hline $\mathrm{Al}$ & 1.70 & $48 \pm 14$ & $4.5 \pm 2.5$ & 38 & 2.7 \\
\hline $\mathrm{Fe}$ & 6.11 & $6.0 \pm 5.0$ & $18 \pm 9.9$ & 3.3 & 11 \\
\hline $\mathrm{Mn}$ & 1.13 & $3.8 \pm 1.6$ & $1.4 \pm 0.36$ & 2.3 & 0.93 \\
\hline $\mathrm{Na}$ & 7.54 & $470 \pm 190$ & $6.8 \pm 6.2$ & 324 & 5.33 \\
\hline $\mathrm{U}$ & 1.07 & $140+63$ & $0.82+0.76$ & 60 & 8.1 \\
\hline $\mathrm{Ni}$ & 1.0 & 1.0 & 1.0 & 1.0 & 1.0 \\
\hline & & & Cumulative & & \\
\hline $\mathrm{Al}$ & 1.70 & 37 & $28+12$ & 16 & 27 \\
\hline $\mathrm{Fe}$ & 6.11 & 6.3 & $77 \pm 20$ & 1.6 & 80 \\
\hline $\mathrm{Mn}$ & 1.13 & 3.1 & $8.6 \pm 1.0$ & 1.4 & 9.5 \\
\hline $\mathrm{Na}$ & 7.54 & 500 & $160 \pm 66$ & 770 & 160 \\
\hline $\mathrm{U}$ & 1.07 & 250 & $20 \pm 0.37$ & 40 & 47 \\
\hline $\mathrm{Ni}$ & 1.0 & 1.0 & $\overline{1} .0$ & 1.0 & 1.0 \\
\hline
\end{tabular}


Tables 4.5.6 and 4.5.7 provide the measured quantities of dissolved uranium and plutonium for the Tank 12H (HM) and 8F (PUREX) samples, respectively. We also include the mole ratios of uranium and plutonium to nickel as previously reported for $\mathrm{Al}$, $\mathrm{Fe}, \mathrm{Mn}, \mathrm{Ni}$ and $\mathrm{Na}$. Uranium and plutonium content in the HM sludge sample measured $3.32 \mathrm{E}-02 \pm 2.34 \mathrm{E}-03 \mathrm{wt} \%$ and $6.62 \mathrm{E}-02 \pm 5.02 \mathrm{E}-04 \mathrm{wt} \%$, respectively. The PUREX sludge sample measured much higher in uranium $(14.2 \pm 0.842 \mathrm{wt} \%)$, but lower in plutonium $(4.51 \mathrm{E}-03 \pm 3.11 \mathrm{E}-05 \mathrm{wt} \%)$ than the HM sludge sample. The average mole ratios of uranium and plutonium to nickel measured 1.81E-02 (U:Ni) and 3.59E-02 (Pu:Ni) for the HM sludge sample and 1.07 (U:Ni) and 3.38E-04 (Pu:Ni) in the PUREX sludge sample. The much lower Pu:Ni ratio in the PUREX sample (3.38E-04) compared to the HM sample (3.59E-02) reflects almost order of magnitude lower plutonium and higher nickel concentrations in the PUREX sample compared to the HM sample.

In general the average quantity of uranium that dissolved from the HM sludge sample increased slightly in the oxalic/citric acid mixture compared to oxalic acid at the same acid:sludge ratio. We also found that the U:Ni mole ratio measured higher in all of the acid solutions compared to that in the initial sludge sample. These results suggest that uranium in the HM sludge sample readily dissolves in either acid and that citrate has a small positive effect on uranium dissolution.

Plutonium dissolution from the HM sludge sample proved low in both acids at the 2:1 acid:sludge ratio. However, at the 50:1 ratio in the oxalic/citric acid mixture, all of the plutonium dissolved after two contacts. We lack ICP-MS data for the 50:1 tests in oxalic acid to determine the extent of plutonium dissolution in this acid solution. There was no consistent trend between the extent of plutonium dissolution and acid solution composition. Also, with the exception of the $2^{\text {nd }}$ contacts for the $2: 1$ acid:sludge tests, the mole ratios of Pu:Ni fell below that originally present in the HM sludge sample. Thus, we conclude that plutonium will dissolve in both acids, but that citrate does not exhibit a solubilizing effect on plutonium under the tested conditions.

Significant fractions of uranium and plutonium dissolved in both acids and increased at the higher sludge:acid ratio in the PUREX sludge sample. Test results indicated higher $\mathrm{U}: \mathrm{Ni}$ and Pu:Ni mole ratios in both acids at either acid:sludge ratios. Note that the PUREX sludge sample contained about 8 times less plutonium and about 8 times more nickel than the HM sludge sample. From these results we conclude that both uranium and plutonium in the PUREX sludge sample readily dissolve in both acid solutions.

We also calculated the weight ratios of several neutron poisons, $\mathrm{Al}, \mathrm{Fe}, \mathrm{Mn}, \mathrm{Ni}$ and $\mathrm{Na}$, to equivalent ${ }^{235} \mathrm{U}$ for the respective sludge samples and each of the acid solution contacts. Tables 4.5.8 and 4.5.9 provide a compilation of these values for the Tank $12 \mathrm{H}$ (HM) and Tank 8F (PUREX) sludge samples, respectively. The weight ratios for the HM sludge sample prior to acid dissolution range from a low of $55.7 \pm 0.983$ for $\mathrm{Ni}$ to a high 
of $322 \pm 8.01$ for Fe. For the PUREX sample we measured weight ratios ranging from a low of $20.7 \pm 2.31$ for $\mathrm{Ni}$ to a high of $1600 \pm 145$ for $\mathrm{Al}$.

Dissolution of the HM sludge sample in 4 wt \% oxalic acid at 2:1 and 50:1 acid:sludge ratio resulted in solutions with lower weight ratios compared to the sludge sample for $\mathrm{Al}$, $\mathrm{Fe}, \mathrm{Mn}, \mathrm{Ni}$ and $\mathrm{Na}$ with the exception of the $2^{\text {nd }}$ contact in the $2: 1$ test, which remained unchanged within the measured experimental variance. Unfortunately, we do not have data on the weight ratios for the $1^{\text {st }}$ contact in the 50:1 tests with oxalic acid to compare the influence of the higher acid ratio. From the elemental analytical results, over twice as much of the sludge dissolved in the $1^{\text {st }}$ contact, but only half as much in the $2^{\text {nd }}$ contact of the 50:1 tests compared to that in the 2:1 tests. Thus, the same trend in weight ratios for the $1^{\text {st }}$ contact in the 50:1 test may not necessarily follow that in the 2:1 tests. From these results we conclude that the residual sludge solids after contact with oxalic acid are not concentrating in fissile isotopes relative to the available neutron poisons such as $\mathrm{Al}, \mathrm{Fe}$, $\mathrm{Mn}$ and Ni.

Dissolution of the HM sludge sample in the oxalic/citric acid mixture at 2:1 and 50:1 acid:sludge ratios generally resulted in solutions with lower weight ratios for $\mathrm{Al}, \mathrm{Fe}, \mathrm{Mn}$, and $\mathrm{Ni}$ and higher weight ratios for $\mathrm{Na}$ compared to the sludge sample. In the 2:1 tests, the weight ratios were well over a magnitude lower for both $\mathrm{Al}$ and Fe. In the 50:1 tests the $1^{\text {st }}$ contact and cumulative weight ratios for $\mathrm{Al}$ measured more than a magnitude lower. The weight ratios for $\mathrm{Mn}$ and $\mathrm{Na}$ in the oxalic/citric acid mixture in the 50:1 ratio tests remained unchanged compared to the original sludge sample. We also observed unchanged ratios for the $2^{\text {nd }}$ contact solutions for Fe and Ni. From these results we conclude that the residual sludge solids after contact with oxalic and citric acid are not concentrated in fissile isotopes relative to the available neutron poisons such as $\mathrm{Al}, \mathrm{Fe}$, $\mathrm{Mn}$ and Ni. In general the acid solutions produced from the 50:1 contacts have weight ratios more similar to that in the original sludge sample compared to those produced at the lower 2:1 acid:sludge ratio. Thus, the oxalic/citric acid mixture provides a more homogeneous dissolution of the sludge than oxalic acid alone.

We observed similar trends in the weight ratios for the PUREX sludge sample compared to that for the HM sludge sample upon dissolution in oxalic and oxalic/citric acid solutions. In oxalic acid, the weight ratios for $\mathrm{Al}, \mathrm{Fe}, \mathrm{Mn}$ and $\mathrm{Ni}$ decreased in both the 2:1 and 50:1 tests with the exception of the Al ratio in the 50:1 test which remained unchanged. Weight ratios for $\mathrm{Al}$ measured more than one order of magnitude lower in the $1^{\text {st }}$ contact and for $\mathrm{Fe}$ in the $1^{\text {st }}$ and $2^{\text {nd }}$ contacts with oxalic acid. Weight ratios for $\mathrm{Na}$ increased in the $1^{\text {st }}$ contact and remained unchanged in the $2^{\text {nd }}$ contact with a 2:1 acid:sludge ratio.

With the exception of $\mathrm{Na}$ and $\mathrm{Al}$ in the 50:1 tests, all of the weight ratios in the acid solutions decreased in the 2:1 and 50:1 tests with the PUREX sludge sample and the oxalic/citric acid mixture. In the 2:1 tests, the weight ratios of $\mathrm{Na}$ increased versus that in the original sludge and remained unchanged in the 50:1 tests. Weight ratios for Fe in the 
2:1 tests the oxalic/citric acid mixture were more than two orders of magnitude lower that of the original sludge sample indicating rather low dissolution of iron in these tests.

From these results we conclude that the residual sludge solids, after contact with oxalic and citric acid, are not concentrated in fissile isotopes relative to the available neutron poisons such as $\mathrm{Al}, \mathrm{Fe}, \mathrm{Mn}$ and $\mathrm{Ni}$. In general the solutions produced from the 2:1 and 50:1 contacts in both acid solutions have very similar ratios. Thus, we conclude that there is no evidence that either acid is better in homogeneously dissolving the PUREX sludge sample. 
Table 4.5.6 Quantities of Uranium and Plutonium Dissolved in the Tank 12H (HM) Sample

\begin{tabular}{|c|c|c|c|c|c|c|c|c|c|c|}
\hline \multicolumn{11}{|c|}{ Tank 12H (HM) } \\
\hline & \multicolumn{5}{|c|}{ Wt \% Uranium Dissolved } & \multicolumn{5}{|c|}{ mole U/mole Ni } \\
\hline & $\begin{array}{c}\text { Sample } \\
\text { Average }\end{array}$ & $\mathbf{O A}$ & $\mathbf{O A}$ & OA/CA & OA/CA & $\begin{array}{l}\text { Sample } \\
\text { mole U/ }\end{array}$ & $\mathbf{O A}$ & $\mathbf{O A}$ & OA/CA & OA/CA \\
\hline Contact & Wt \% U & $2: 1$ & 50:1 & $2: 1$ & $50: 1$ & mole $\mathrm{Ni}$ & $2: 1$ & $50: 1$ & $2: 1$ & $50: 1$ \\
\hline 1 & 3.32E-02 & $11+2.5$ & - & $18+1.4$ & 96 & $1.81 \mathrm{E}-02$ & $\begin{array}{c}0.16 \pm \\
0.031\end{array}$ & - & $\begin{array}{l}0.26 \pm \\
0.0038\end{array}$ & 0.03 \\
\hline 2 & $3.32 \mathrm{E}-02$ & $20+1.7$ & $5.6+0.37$ & $24+4.2$ & 8.8 & $1.81 \mathrm{E}-02$ & $0.35 \pm 0.13$ & $\begin{array}{c}0.027 \pm \\
0.020\end{array}$ & $\begin{array}{l}0.19 \pm \\
0.036\end{array}$ & 0.015 \\
\hline Cumulative & 3.32E-02 & $31+4.1$ & - & $42+5.6$ & 105 & $1.81 \mathrm{E}-02$ & $\begin{array}{l}0.24 \pm \\
0.0023\end{array}$ & - & $\begin{array}{l}0.22 \pm \\
0.023\end{array}$ & 0.028 \\
\hline
\end{tabular}

\begin{tabular}{|c|c|c|c|c|c|c|c|c|c|c|}
\hline \multirow[b]{3}{*}{ Contact } & \multicolumn{5}{|c|}{ Wt\% Plutonium Dissolved } & \multicolumn{5}{|c|}{ mole Pu/mole Ni } \\
\hline & $\begin{array}{c}\text { Sample } \\
\text { Average }\end{array}$ & $\mathbf{O A}$ & $\mathbf{O A}$ & OA/CA & OA/CA & $\begin{array}{l}\text { Sample } \\
\text { mole Pu/ }\end{array}$ & $\mathbf{O A}$ & $\mathbf{O A}$ & OA/CA & OA/CA \\
\hline & $\mathrm{Wt} \% \mathrm{Pu}$ & $2: 1$ & 50:1 & $2: 1$ & $50: 1$ & mole $\mathrm{Ni}$ & $2: 1$ & $50: 1$ & $2: 1$ & 50:1 \\
\hline 1 & $6.62 \mathrm{E}-02$ & $0.74+0.15$ & - & $3.4+0.27$ & 92 & $3.59 \mathrm{E}-02$ & $\begin{array}{c}2.8 \mathrm{E}-03 \pm \\
4.5 \mathrm{E}-04 \\
\end{array}$ & - & $\begin{array}{c}9.9 \mathrm{E}-03 \pm \\
1.4 \mathrm{E}-04\end{array}$ & $5.7 \mathrm{E}-03$ \\
\hline 2 & $6.62 \mathrm{E}-02$ & $15+2.4$ & $15+4.4$ & $4.3+0.38$ & 7.3 & $3.59 \mathrm{E}-02$ & $\begin{array}{c}5.0 \mathrm{E}-02 \pm \\
1.4 \mathrm{E}-02\end{array}$ & $\begin{array}{c}1.4 \mathrm{E}-02 \pm \\
4.4 \mathrm{E}-03\end{array}$ & $\begin{array}{c}6.8 \mathrm{E}-02 \pm \\
6.6 \mathrm{E}-04\end{array}$ & $2.5 \mathrm{E}-03$ \\
\hline Cumulative & $6.62 \mathrm{E}-02$ & $16+2.2$ & - & $7.7+0.64$ & 100 & $3.59 \mathrm{E}-02$ & $\begin{array}{c}2.4 \mathrm{E}-02 \pm \\
2.4 \mathrm{E}-03\end{array}$ & - & $\begin{array}{c}7.9 \mathrm{E}-03 \pm \\
4.5 \mathrm{E}-04\end{array}$ & $5.2 \mathrm{E}-03$ \\
\hline
\end{tabular}


Table 4.5.7 Quantities of Uranium and Plutonium Dissolved in the Tank 8F (PUREX) Sample

\begin{tabular}{|c|c|c|c|c|c|c|c|c|c|c|}
\hline \multicolumn{11}{|c|}{ Tank 8F (PUREX) } \\
\hline & \multicolumn{5}{|c|}{ Wt \% Uranium Dissolved } & \multicolumn{5}{|c|}{ mole U/mole Ni } \\
\hline & $\begin{array}{c}\text { Sample } \\
\text { Average }\end{array}$ & $\mathbf{O A}$ & $\mathbf{O A}$ & OA/CA & OA/CA & $\begin{array}{l}\text { Sample } \\
\text { mole U/ }\end{array}$ & $\mathbf{O A}$ & $\mathbf{O A}$ & OA/CA & OA/CA \\
\hline Contact & $\mathbf{W t} \% \mathbf{U}$ & $2: 1$ & 50:1 & $2: 1$ & 50:1 & mole Ni & $2: 1$ & 50:1 & $2: 1$ & 50:1 \\
\hline 1 & 14.2 & 18 & $70+0.72$ & 14 & $74+1.2$ & 1.07 & 16 & $23 \pm 12$ & 26 & $42 \pm 11$ \\
\hline 2 & 14.2 & 46 & $1.1+1.0$ & 23 & 1.4 & 1.07 & $72 \pm 33$ & $0.79 \pm 0.80$ & 60 & 0.54 \\
\hline \multirow[t]{4}{*}{ Cumulative } & 14.2 & 64 & $71+0.28$ & 38 & $75+1.2$ & 1.07 & 31 & $16 \pm 6.7$ & 40 & $31 \pm 20$ \\
\hline & \multicolumn{5}{|c|}{ Wt\% Plutonium Dissolved } & \multicolumn{5}{|c|}{ mole Pu/mole Ni } \\
\hline & Sample & $\mathbf{O A}$ & $\mathbf{O A}$ & OA/CA & OA/CA & Sample & $\mathbf{O A}$ & OA & OA/CA & OA/CA \\
\hline & $\begin{array}{c}\text { Average } \\
\text { Wt \% Pu }\end{array}$ & $2: 1$ & 50:1 & $2: 1$ & 50:1 & $\begin{array}{c}\text { mole } \mathrm{Pu} / \\
\text { mole } \mathrm{Ni}\end{array}$ & $2: 1$ & $50: 1$ & $2: 1$ & 50:1 \\
\hline 1 & $4.51 \mathrm{E}-03$ & 4 & $100+24$ & 2.2 & $100+12$ & $3.38 \mathrm{E}-04$ & $1.10 \mathrm{E}-03$ & $\begin{array}{c}1.0 \mathrm{E}-02 \pm \\
3.2 \mathrm{E}-03\end{array}$ & $1.3 \mathrm{E}-03$ & $\begin{array}{c}1.9 \mathrm{E}-02 \pm \\
7.2 \mathrm{E}-03\end{array}$ \\
\hline 2 & $4.51 \mathrm{E}-03$ & 11 & $6.3+8.9$ & 10 & 11 & $3.38 \mathrm{E}-04$ & $3.70 \mathrm{E}-03$ & $\begin{array}{c}1.5 \mathrm{E}-03 \pm \\
2.1 \mathrm{E}-03\end{array}$ & $8.2 \mathrm{E}-03$ & $1.4 \mathrm{E}-03$ \\
\hline Cumulative & $4.51 \mathrm{E}-03$ & 15 & $110+15$ & 12 & $106+13$ & $3.38 \mathrm{E}-04$ & $2.30 \mathrm{E}-03$ & $\begin{array}{l}7.2 \mathrm{E}-03 \pm \\
2.2 \mathrm{E}-03\end{array}$ & $4.2 \mathrm{E}-03$ & $\begin{array}{c}1.4 \mathrm{E}-02 \pm \\
1.0 \mathrm{E}-02\end{array}$ \\
\hline
\end{tabular}


Table 4.5.8 Weight Ratios of Neutron Poisons to Equivalent ${ }^{235} \mathrm{U}$ in Tank 12H (HM) Sludge Sample

\begin{tabular}{|c|c|c|c|c|c|c|c|c|c|c|}
\hline & & & & \multicolumn{3}{|c|}{ Tank 12H (HM) } & \multirow[b]{3}{*}{ OA/CA } & \multirow[b]{3}{*}{ OA/CA } & \multirow[b]{3}{*}{ OA/CA } & \multirow[b]{3}{*}{ OA/CA } \\
\hline & & & \multirow[b]{2}{*}{ OA } & \multicolumn{3}{|c|}{ Weight Ratios (Element to Equivalent U-235) } & & & & \\
\hline & & & & $\mathbf{O A}$ & OA & OA & & & & \\
\hline & Sludge Sample & Sludge Sample & $2: 1$ & $2: 1$ & $50: 1$ & $50: 1$ & $2: 1$ & $2: 1$ & $50: 1$ & $50: 1$ \\
\hline Contact 1 & Average & Std Dev & Average & Std Dev & Average & Std Dev & Average & Std Dev & Average & Std Dev \\
\hline Al & $1.60 \mathrm{E}+03$ & $1.45 \mathrm{E}+02$ & $3.40 \mathrm{E}+02$ & $2.00 \mathrm{E}+01$ & nd & nd & $8.40 \mathrm{E}+00$ & $5.26 \mathrm{E}-01$ & $2.43 \mathrm{E}+01$ & nd \\
\hline $\mathbf{F e}$ & $1.83 \mathrm{E}+02$ & $2.06 \mathrm{E}+01$ & $1.28 \mathrm{E}+02$ & $2.69 \mathrm{E}+00$ & nd & nd & $1.20 \mathrm{E}+00$ & $2.05 \mathrm{E}-02$ & $5.03 \mathrm{E}+01$ & nd \\
\hline Mn & $9.24 \mathrm{E}+01$ & $9.16 \mathrm{E}+00$ & $5.38 \mathrm{E}+01$ & $1.48 \mathrm{E}+00$ & nd & nd & $7.53 \mathrm{E}+00$ & $1.36 \mathrm{E}+00$ & $8.18 \mathrm{E}+01$ & nd \\
\hline $\mathrm{Ni}$ & $2.07 \mathrm{E}+01$ & $2.31 \mathrm{E}+00$ & $6.77 \mathrm{E}+00$ & 1.19E-01 & nd & nd & $3.15 \mathrm{E}+00$ & $1.74 \mathrm{E}-02$ & $1.10 \mathrm{E}+01$ & nd \\
\hline $\mathbf{N a}$ & $9.60 \mathrm{E}+01$ & $2.48 \mathrm{E}+01$ & $2.19 \mathrm{E}+03$ & $3.05 \mathrm{E}+01$ & nd & nd & $6.22 \mathrm{E}+02$ & $4.45 \mathrm{E}+01$ & $7.52 \mathrm{E}+01$ & nd \\
\hline Contact 2 & & & & & & & & & & nd \\
\hline Al & $1.60 \mathrm{E}+03$ & $1.45 \mathrm{E}+02$ & $5.48 \mathrm{E}+01$ & $3.26 \mathrm{E}+00$ & $1.13 \mathrm{E}+02$ & $7.89 \mathrm{E}-01$ & $2.53 \mathrm{E}+01$ & $2.96 \mathrm{E}-01$ & $3.78 \mathrm{E}+02$ & nd \\
\hline $\mathbf{F e}$ & $1.83 \mathrm{E}+02$ & $2.06 \mathrm{E}+01$ & $8.99 \mathrm{E}+01$ & $4.81 \mathrm{E}-01$ & $2.86 \mathrm{E}+01$ & $2.12 \mathrm{E}+00$ & $5.01 \mathrm{E}+00$ & $6.83 \mathrm{E}-01$ & $2.07 \mathrm{E}+02$ & nd \\
\hline Mn & $9.24 \mathrm{E}+01$ & $9.16 \mathrm{E}+00$ & $6.06 \mathrm{E}+01$ & $1.59 \mathrm{E}-01$ & $1.42 \mathrm{E}+01$ & $1.12 \mathrm{E}+00$ & $1.87 \mathrm{E}+01$ & $2.85 \mathrm{E}+00$ & $6.65 \mathrm{E}+01$ & nd \\
\hline $\mathbf{N i}$ & $2.07 \mathrm{E}+01$ & $2.31 \mathrm{E}+00$ & $1.13 \mathrm{E}+00$ & $1.77 \mathrm{E}-01$ & $4.50 \mathrm{E}+00$ & $7.80 \mathrm{E}-01$ & $4.46 \mathrm{E}+00$ & 3.99E-01 & $2.42 \mathrm{E}+01$ & nd \\
\hline $\mathbf{N a}$ & $9.60 \mathrm{E}+01$ & $2.48 \mathrm{E}+01$ & $1.15 \mathrm{E}+02$ & $5.45 \mathrm{E}+00$ & $1.90 \mathrm{E}+01$ & $2.65 \mathrm{E}+00$ & $2.27 \mathrm{E}+02$ & $7.75 \mathrm{E}+00$ & $2.86 \mathrm{E}+02$ & nd \\
\hline Cumulative & & & & & & & & & & nd \\
\hline Al & $1.60 \mathrm{E}+03$ & $1.45 \mathrm{E}+02$ & $9.81 \mathrm{E}+01$ & $6.91 \mathrm{E}+00$ & nd & nd & $1.79 \mathrm{E}+01$ & $1.24 \mathrm{E}-01$ & $5.07 \mathrm{E}+01$ & nd \\
\hline $\mathbf{F e}$ & $1.83 \mathrm{E}+02$ & $2.06 \mathrm{E}+01$ & $9.57 \mathrm{E}+01$ & $1.50 \mathrm{E}-01$ & nd & nd & $3.33 \mathrm{E}+00$ & $3.34 \mathrm{E}-01$ & $6.20 \mathrm{E}+01$ & nd \\
\hline Mn & $9.24 \mathrm{E}+01$ & $9.16 \mathrm{E}+00$ & $5.95 \mathrm{E}+01$ & $6.31 \mathrm{E}-02$ & nd & nd & $1.37 \mathrm{E}+01$ & 8.89E-01 & $8.07 \mathrm{E}+01$ & nd \\
\hline $\mathbf{N i}$ & $2.07 \mathrm{E}+01$ & $2.31 \mathrm{E}+00$ & $1.99 \mathrm{E}+00$ & $1.10 \mathrm{E}-01$ & nd & nd & $3.88 \mathrm{E}+00$ & $2.03 \mathrm{E}-01$ & $1.20 \mathrm{E}+01$ & nd \\
\hline $\mathbf{N a}$ & $9.60 \mathrm{E}+01$ & $2.48 \mathrm{E}+01$ & $4.30 \mathrm{E}+02$ & $1.73 \mathrm{E}+01$ & nd & nd & $4.00 \mathrm{E}+02$ & $2.82 \mathrm{E}+01$ & $9.09 \mathrm{E}+01$ & nd \\
\hline & & & & $\mathrm{OA}$ & ic acid, $\mathrm{CA}=$ & ric acid & & & & \\
\hline & & & & & not determir & & & & & \\
\hline & & & & $2: 1$ and & er to acid:slu & ratio $(\mathrm{v} / \mathrm{w})$ & & & & \\
\hline
\end{tabular}


Table 4.5.9 Weight Ratios of Neutron Poisons to Equivalent ${ }^{235} \mathrm{U}$ in Tank 8F (PUREX) Sludge Sample

\begin{tabular}{|c|c|c|c|c|c|c|c|c|c|c|}
\hline & & & & \multicolumn{3}{|c|}{ Tank 8F (PUREX) } & & & & \\
\hline & & & & \multicolumn{3}{|c|}{ Weight Ratios (Element to Equivalent U-235) } & & & & \\
\hline & & & $\mathbf{O A}$ & $\mathbf{O A}$ & $\mathbf{O A}$ & $\mathbf{O A}$ & OA/CA & OA/CA & OA/CA & OA/CA \\
\hline & Sludge Sample & Sludge Sample & $2: 1$ & $2: 1$ & 50:1 & 50:1 & $2: 1$ & $2: 1$ & 50:1 & 50:1 \\
\hline Contact 1 & Average & Std Dev & Average & Std Dev & Average & Std Dev & Average & Std Dev & Average & Std Dev \\
\hline Al & $4.33 \mathrm{E}+01$ & $1.33 \mathrm{E}+00$ & $6.66 \mathrm{E}-01$ & nd & $3.95 \mathrm{E}+01$ & $1.64 \mathrm{E}+00$ & $1.03 \mathrm{E}+00$ & nd & $3.20 \mathrm{E}+01$ & $4.06 \mathrm{E}+00$ \\
\hline $\mathbf{F e}$ & $3.22 \mathrm{E}+02$ & $8.01 \mathrm{E}+00$ & 4.73E-01 & nd & $2.26 \mathrm{E}+02$ & $1.19 \mathrm{E}+01$ & $8.22 \mathrm{E}-01$ & nd & $1.46 \mathrm{E}+02$ & $5.41 \mathrm{E}+01$ \\
\hline Mn & $5.84 \mathrm{E}+01$ & 7.89E-01 & $1.10 \mathrm{E}+00$ & nd & $2.61 \mathrm{E}+01$ & $2.92 \mathrm{E}+00$ & $2.08 \mathrm{E}+00$ & nd & $2.40 \mathrm{E}+01$ & $1.76 \mathrm{E}+00$ \\
\hline $\mathrm{Ni}$ & $5.57 \mathrm{E}+01$ & $9.83 \mathrm{E}-01$ & $4.75 \mathrm{E}+00$ & nd & $2.42 \mathrm{E}+00$ & $5.29 \mathrm{E}-01$ & $3.04 \mathrm{E}+00$ & nd & $1.19 \mathrm{E}+00$ & $1.84 \mathrm{E}-01$ \\
\hline $\mathbf{N a}$ & $1.64 \mathrm{E}+02$ & $1.05 \mathrm{E}+01$ & $8.87 \mathrm{E}+02$ & nd & $1.98 \mathrm{E}+02$ & $8.96 \mathrm{E}+00$ & $1.30 \mathrm{E}+03$ & nd & $1.85 \mathrm{E}+02$ & $3.87 \mathrm{E}+00$ \\
\hline \multicolumn{11}{|l|}{ Contact 2} \\
\hline Al & $4.33 \mathrm{E}+01$ & $1.33 \mathrm{E}+00$ & $2.17 \mathrm{E}+01$ & $1.53 \mathrm{E}+00$ & $4.24 \mathrm{E}+01$ & nd & $2.07 \mathrm{E}+01$ & nd & $2.02 \mathrm{E}+00$ & nd \\
\hline $\mathrm{Fe}$ & $3.22 \mathrm{E}+02$ & $8.01 \mathrm{E}+00$ & $4.91 \mathrm{E}+00$ & $1.20 \mathrm{E}+00$ & $3.42 \mathrm{E}+02$ & nd & $3.75 \mathrm{E}+00$ & nd & $1.80 \mathrm{E}+01$ & nd \\
\hline Mn & $5.84 \mathrm{E}+01$ & 7.89E-01 & $3.43 \mathrm{E}+00$ & $3.83 \mathrm{E}-02$ & $2.27 \mathrm{E}+01$ & nd & $2.60 \mathrm{E}+00$ & nd & $1.44 \mathrm{E}+00$ & nd \\
\hline $\mathbf{N i}$ & $5.57 \mathrm{E}+01$ & $9.83 \mathrm{E}-01$ & $1.05 \mathrm{E}+00$ & $2.26 \mathrm{E}-01$ & $1.47 \mathrm{E}+01$ & nd & $1.19 \mathrm{E}+00$ & nd & $1.65 \mathrm{E}+00$ & nd \\
\hline $\mathbf{N a}$ & $1.64 \mathrm{E}+02$ & $1.05 \mathrm{E}+01$ & $1.77 \mathrm{E}+02$ & $2.67 \mathrm{E}+00$ & $6.41 \mathrm{E}+01$ & nd & $1.51 \mathrm{E}+02$ & nd & $3.45 \mathrm{E}+00$ & nd \\
\hline \multicolumn{11}{|l|}{ Cumulative } \\
\hline Al & $4.33 \mathrm{E}+01$ & $1.33 \mathrm{E}+00$ & $1.79 \mathrm{E}+01$ & nd & $4.02 \mathrm{E}+01$ & $1.16 \mathrm{E}+00$ & $1.38 \mathrm{E}+01$ & nd & $2.32 \mathrm{E}+01$ & $2.52 \mathrm{E}+00$ \\
\hline $\mathrm{Fe}$ & $3.22 \mathrm{E}+02$ & $8.01 \mathrm{E}+00$ & $2.51 \mathrm{E}+00$ & nd & $2.36 \mathrm{E}+02$ & $1.27 \mathrm{E}+01$ & $2.72 \mathrm{E}+00$ & nd & $9.44 \mathrm{E}+01$ & $1.73 \mathrm{E}+01$ \\
\hline Mn & $5.84 \mathrm{E}+01$ & 7.89E-01 & $2.88 \mathrm{E}+00$ & nd & $2.67 \mathrm{E}+01$ & $3.31 \mathrm{E}+00$ & $2.42 \mathrm{E}+00$ & nd & $1.76 \mathrm{E}+01$ & $2.74 \mathrm{E}+00$ \\
\hline $\mathrm{Ni}$ & $5.57 \mathrm{E}+01$ & $9.83 \mathrm{E}-01$ & $2.24 \mathrm{E}+00$ & nd & $3.39 \mathrm{E}+00$ & $6.19 \mathrm{E}-01$ & $1.84 \mathrm{E}+00$ & nd & $1.30 \mathrm{E}+00$ & $1.82 \mathrm{E}-01$ \\
\hline \multirow[t]{4}{*}{$\mathbf{N a}$} & $1.64 \mathrm{E}+02$ & $1.05 \mathrm{E}+01$ & $3.62 \mathrm{E}+02$ & nd & $1.94 \mathrm{E}+02$ & $5.26 \mathrm{E}+00$ & $5.56 \mathrm{E}+02$ & nd & $1.40 \mathrm{E}+02$ & $3.12 \mathrm{E}+01$ \\
\hline & & & & \multicolumn{3}{|c|}{$\mathrm{OA}=$ oxalic acid, $\mathrm{CA}=$ citric acid } & & & & \\
\hline & & & & \multicolumn{3}{|c|}{ nd $=$ not determinable } & & & & \\
\hline & & & & \multicolumn{3}{|c|}{ 2:1 and 5:1 refer to acid:sludge ratio (v/w) } & & & & \\
\hline
\end{tabular}




\subsection{Evaluation of Corrosion Testing Results for Carbon Steel in Contact with Organic Acid Solutions}

\section{$\underline{\text { 4.6.1 Corrosion Mechanisms }}$}

\subsubsection{Oxalic Acid}

Oxalic acid solutions have been frequently utilized to decontaminate steel components at nuclear facilities. The Savannah River Site (SRS) has utilized oxalic acid to perform sludge heel removal in two waste tanks ${ }^{12,13}$ and also to clean out of the reactor heat exchanger system. ${ }^{14}$ Oxalic acid is successful in these types of processes because it is a sufficiently strong and oxidizing acid that is able to dissolve iron oxides and corrode steel. These reactions tend to dislodge scale that might adhere to the surface and thus successfully decontaminate the surface.

The corrosion of iron in oxalic acid has also been investigated for many years. ${ }^{15}$ The anodic reactions are reported to be:

$$
\begin{aligned}
& \mathrm{Fe}=\mathrm{Fe}^{2+}+2 \mathrm{e}^{-} \\
& \mathrm{Fe}=\mathrm{Fe}^{3+}+3 \mathrm{e}^{-}
\end{aligned}
$$

The cathodic reaction is the reduction of hydrogen ion to hydrogen gas. Two other reactions occur that impact the corrosion rate.

$$
\begin{aligned}
& \mathrm{Fe}^{3+}+3 \mathrm{C}_{2} \mathrm{O}_{4}{ }^{2-}=\mathrm{Fe}\left(\mathrm{C}_{2} \mathrm{O}_{4}\right)_{3}{ }^{3-} \\
& 2 \mathrm{Fe}\left(\mathrm{C}_{2} \mathrm{O}_{4}\right)_{3}{ }^{3-}=2 \mathrm{FeC}_{2} \mathrm{O}_{4}+3 \mathrm{C}_{2} \mathrm{O}_{4}{ }^{2-}+2 \mathrm{CO}_{2}
\end{aligned}
$$

The ferric oxalate anion from equation 3 is soluble and is recognizable by its lime green color in solution. This anion decomposes photocatalytically over a period of days per equation 4 , depending on the radiation intensity in the visible range. Consequently, a ferrous oxalate complex precipitates on the surface of the steel and markedly depresses the iron corrosion rate and passivates the steel. Thus, if ferric oxalate is not present near the surface, or there is not enough light, the process of passivation will be hindered. The corrosion is typically uniform (i.e., no pitting) due to this film. Therefore, if contact time between the acid and the steel is not excessively prolonged, corrosion will not be significant.

On the other hand, the precipitation of these salts reduces the effective cleaning power of the oxalic acid. ${ }^{16}$ In order to maintain the cleaning power, the acid could be refreshed and consequently the corrosion process would also be renewed. Tests have shown that if the acid is refreshed daily, less of the film forms and the corrosion rate approximately doubles. $^{12}$ Thus when utilizing oxalic in chemical cleaning operations a balance between effective cleaning and minimizing corrosion must be achieved. 


\subsubsection{Citric Acid}

Citric acid is not typically utilized by itself in chemical cleaning operations primarily because it does not effectively dissolve metal oxides. ${ }^{17}$ However, because the citric acid is able to complex with metal cations to form chelates, it has been utilized in combination with other acids. When a metal ion is chelated by citric acid, it remains in solution and is unable to react further. Thus, as $\mathrm{Fe}^{2+}$ and $\mathrm{Fe}^{3+}$ cations are produced by the corrosion reaction in the acidic solution, they are captured by the citric acid ligand and prevented from forming oxides or other insoluble complexes on the surface of the metal. These insoluble complexes typically inhibit corrosion and therefore corrosion rates in citric acid alone would likely be greater than that for an acid that formed an oxide.

\subsubsection{Oxalic + Citric Acid}

A combination of organic acids is frequently utilized in a chemical cleaning process. ${ }^{18}$ One such combination is oxalic and citric acid. The oxalic acid is effective for dissolution of the metal oxides, while the citric acid reduces the amount of ferrous oxalate precipitates that form on the surface of the metal. This competition for the metal cations therefore maintains the effective cleaning power of the oxalic acid. However, because fewer of the metal ions are available to form the protective film, the metal will corrode at a faster rate. Thus, optimizing the concentrations of the acids and the temperature of the cleaning process such that the cleaning power is maximized, while the corrosion rate is minimized, has been the goal of much of the research.

\subsubsection{Review of Experimentally Determined Corrosion Rates}

A review was performed of the experimentally determined corrosion rates for oxalic acid, citric acid, and a combination of oxalic and citric acids. The important variables impacting the corrosion rate were acid concentration, carbon content of the metal, temperature and length of exposure. Each of these variables is discussed below.

\subsubsection{Oxalic Acid}

Table 4.6.2.1 shows corrosion rate data for carbon steel in oxalic acid under various environmental conditions. Reference 12 data was collected from coupon tests that were performed at SRS in order to provide the technical basis for chemical cleaning of Tank $16 \mathrm{H}$. Reference 14 data was collected from coupon tests that were performed at SRS in support of cleaning of the reactor heat exchangers. Reference 1 data was collected from a recent Russian investigation on the effectiveness of oxalic acid cleaning of sludge. References 9 and 10 were from separate coupon studies performed at Pacific Northwest National Laboratory that were related to the clean-out of high level waste tanks at West Valley. Reference 11 data was collected from a journal article written by a group from Egypt that performed electrochemical tests to determine among other things the influence of carbon content in the metal on the corrosion rate. 
Several observations can be made with regard to the corrosion rate data.

- The corrosion rate decreases as the concentration of oxalic acid increases. This observation is probably related to the limited amount of ferrous oxalate forms and is available to adsorb to the metal surface at the lower acid concentrations.

- There appears to be a concentration of oxalic acid (between 0.2 to $0.45 \mathrm{M}$ ) at which further increase in the concentration does not retard the corrosion rate any further. This observation may be related to the possibility that the available cathodic sites to which the ferrous oxide may attach have become saturated.

- Temperature has a strong effect on the corrosion rate. The corrosion rate appears to be at a maximum at a temperature of $50^{\circ} \mathrm{C}$.

- The corrosion rate in general increases due to agitation. The agitation is expected to increase the diffusion of reactants through the ferrous oxalate layer and hence increase the corrosion rate. However, the data in reference 20 suggests contrary behavior. The author was unable to explain this behavior.

- The corrosion rate is a maximum at a carbon concentration in the metal of approximately $0.5 \mathrm{wt} . \%$. This correlates with a maximum in the area of the $\mathrm{Fe}_{3} \mathrm{C}$ phase (cathodic sites) at approximately $0.6 \mathrm{wt} . \%$ carbon.

In the past, SRS has performed chemical cleaning of sludge with solutions that were less than $0.9 \mathrm{M}$ and at temperatures of approximately $85^{\circ} \mathrm{C}$. The contact times were limited to less than 2 weeks. Since the acid was refreshed and stirred during the operation, the corrosion rate would be expected to be approximately double the rate shown for Reference 12 . Therefore, the metal loss during this cleaning process was likely on the order of $2-3$ E-05 inches per hour. 
Table 4.6.2.1. Oxalic Acid Corrosion Rate Data

\begin{tabular}{|c|c|c|c|c|c|c|}
\hline Type of Test & $\begin{array}{c}\text { Steel } \\
\text { (wt.\% } \\
\text { carbon) } \\
\end{array}$ & $\begin{array}{c}\text { Solution } \\
\text { Concentration } \\
(\mathrm{M})\end{array}$ & $\begin{array}{c}\text { Temperature } \\
\left({ }^{\circ} \mathrm{C}\right)\end{array}$ & $\begin{array}{c}\text { Test } \\
\text { Duration } \\
\text { (hours) }\end{array}$ & $\begin{array}{c}\text { Corrosion } \\
\text { Rate } \times 10^{-5} \\
\text { (inches/hour) }\end{array}$ & Reference \\
\hline \multirow{9}{*}{ Coupon } & \multirow{9}{*}{ Max. 0.3} & \multirow{3}{*}{0.45} & 75 & 336 & 0.23 & \multirow{9}{*}{12} \\
\hline & & & 85 & 168 & 0.30 & \\
\hline & & & 95 & 168 & 0.25 & \\
\hline & & \multirow{3}{*}{0.91} & 75 & 336 & 0.23 & \\
\hline & & & 85 & 168 & 0.30 & \\
\hline & & & 95 & 168 & 0.25 & \\
\hline & & \multirow{3}{*}{1.39} & 75 & 336 & 0.23 & \\
\hline & & & 85 & 168 & 0.30 & \\
\hline & & & 95 & 168 & 0.33 & \\
\hline \multirow{3}{*}{ Coupon } & \multirow{3}{*}{0.06} & \multirow{3}{*}{0.19} & 20 & 46 & 0.18 & \multirow{3}{*}{1} \\
\hline & & & 80 & 46 & 0.39 & \\
\hline & & & Boiling point & 6 & 1.83 & \\
\hline $\begin{array}{l}\text { Coupon during } \\
\text { bench scale } \\
\text { sludge } \\
\text { dissolution } \\
\text { (stirring) }\end{array}$ & 0.06 & 0.89 & 20 & 24 & 0.63 & 1 \\
\hline \multirow{6}{*}{ Coupon } & \multirow{6}{*}{$\begin{array}{l}\text { Max. } \\
0.18\end{array}$} & \multirow{3}{*}{0.45} & 50 & 168 & 0.42 to 1.35 & \multirow{6}{*}{19} \\
\hline & & & 50 & 336 & 0.86 to 1.26 & \\
\hline & & & 50 & 504 & 1.44 to 1.88 & \\
\hline & & \multirow{3}{*}{0.91} & 50 & 168 & 0.34 to 0.53 & \\
\hline & & & 50 & 336 & 0.18 to 0.23 & \\
\hline & & & 50 & 504 & 0.18 to 0.23 & \\
\hline \multirow{12}{*}{ Coupon } & \multirow{12}{*}{$\begin{array}{l}\text { Max. } \\
0.18\end{array}$} & \multirow{6}{*}{0.45} & 27 & 48 & 0.22 & \multirow{12}{*}{20} \\
\hline & & & 27 & 96 & 0.30 & \\
\hline & & & 27 & 144 & 0.45 & \\
\hline & & & 50 & 48 & 0.99 & \\
\hline & & & 50 & 96 & 1.72 & \\
\hline & & & 50 & 144 & 1.82 & \\
\hline & & \multirow{6}{*}{0.91} & 27 & 48 & 0.22 & \\
\hline & & & 27 & 96 & 0.29 & \\
\hline & & & 27 & 144 & 0.45 & \\
\hline & & & 50 & 48 & 1.1 & \\
\hline & & & 50 & 96 & 1.59 & \\
\hline & & & 50 & 144 & 1.6 & \\
\hline \multirow{3}{*}{$\begin{array}{l}\text { Coupon } \\
\text { (Stirring) }\end{array}$} & \multirow{3}{*}{$\begin{array}{c}\text { Max. } \\
0.18\end{array}$} & \multirow{3}{*}{0.91} & 50 & 48 & 0.44 & \multirow{3}{*}{20} \\
\hline & & & 50 & 96 & 0.63 & \\
\hline & & & 50 & 144 & 0.48 & \\
\hline & 0.1 & & & & 0.6 & \\
\hline & 0.25 & & & & 0.9 & \\
\hline Electrochemical & 0.5 & $0.05(\mathrm{pH} 2.8)$ & 30 & NA & 2.1 & 21 \\
\hline & 0.65 & & & & 0.9 & \\
\hline & 0.75 & & & & 0.3 & \\
\hline & & & 20 & & 1.25 & \\
\hline Coupon & NA & 0.001 & 38 & 24 & 1.67 & 14 \\
\hline & & & 72 & & 2.5 & \\
\hline
\end{tabular}




\subsubsection{Citric Acid}

Table 4.6.2.2 shows corrosion rate data for carbon steel in citric acid under various environmental conditions. Reference 21 data was collected from a journal article written by a group from Egypt that performed electrochemical tests that among other things compared the corrosion rates of iron in oxalic acid versus those in citric acid. Reference 16 data was collected from coupon tests that were examining the corrosiveness of mixtures of organic acids on carbon steel. Citric acid was utilized for the control experiment. Reference 22 data was obtained from the literature and its application is unknown.

Several observations can be made in regard to the corrosion rate data.

- The rate of corrosion is 2 to 3 times greater in citric acid than in oxalic acid. This increase was expected due to the lack of an insoluble complex (oxide or oxalate) on the metal surface.

- The effect of temperature on the corrosion rate appears to be greater for citric acid than for oxalic acid. An increase in temperature will significantly increase the corrosion rate.

- Flowing water provides a means by which the solution may be refreshed and agitated. The result is relatively high corrosion rates. The corrosion rates shown in Table 4.6.2.2 are equivalent to 3 to 4 inches per year. Or, if this process were allowed to occur for 2 weeks it is estimated that approximately 0.14 inches (16\% of the wall thickness) of the metal could be lost.

Table 4.6.2.2. Citric Acid Corrosion Data

\begin{tabular}{|c|c|c|c|c|c|c|}
\hline Type of Test & $\begin{array}{c}\text { Steel (wt.\% } \\
\text { carbon) }\end{array}$ & $\begin{array}{c}\text { Solution } \\
\text { Concentration } \\
\text { (M) }\end{array}$ & $\begin{array}{c}\text { Temperature } \\
\left({ }^{\circ} \mathrm{C}\right)\end{array}$ & $\begin{array}{c}\text { Test } \\
\text { Duration } \\
\text { (hours) }\end{array}$ & $\begin{array}{c}\text { Corrosion } \\
\text { Rate } \times 10^{-5} \\
\text { (inches/hour) }\end{array}$ & Reference \\
\hline \multirow[t]{5}{*}{ Electrochemical } & 0.1 & \multirow{5}{*}{$0.05(\mathrm{pH} 2.8)$} & \multirow{5}{*}{30} & \multirow{5}{*}{ NA } & 1.30 & \multirow{5}{*}{21} \\
\hline & 0.25 & & & & 1.50 & \\
\hline & 0.5 & & & & 3.12 & \\
\hline & 0.65 & & & & 1.64 & \\
\hline & 0.75 & & & & 1.47 & \\
\hline \multirow{2}{*}{$\begin{array}{c}\text { Coupon in } \\
\text { flowing water - } \\
6 \mathrm{~cm} / \mathrm{s}\end{array}$} & \multirow[t]{2}{*}{ Max. 0.25} & \multirow[t]{2}{*}{0.004} & 90 & \multirow[t]{2}{*}{22} & $27.3 \pm 3.9$ & \multirow[t]{2}{*}{16} \\
\hline & & & 117 & & $42.9 \pm 15.6$ & \\
\hline \multirow[t]{2}{*}{ NA } & \multirow[t]{2}{*}{ NA } & \multirow[t]{2}{*}{3.24} & 25 & \multirow[t]{2}{*}{ NA } & 2.1 & \multirow[t]{2}{*}{22} \\
\hline & & & 50 & & 14.7 & \\
\hline
\end{tabular}




\subsubsection{Oxalic + Citric Acid Mixtures}

Table 4.6.2.3 shows corrosion rate data for carbon steel in a combination of oxalic and citric acid under various environmental conditions. Reference 1 data was collected from a recent Russian investigation on the effectiveness of oxalic and citric acid cleaning of sludge. Reference 16 data was collected from coupon tests that were examining the corrosiveness of mixtures of organic acids on carbon steel. Reference 12 data was collected from coupon tests performed at SRS that were examining the corrosiveness of a proprietary decontamination solution on carbon steel. The solution was a blend of oxalic, citric, and tartaric acids along with a corrosion inhibitor and surfactants.

Several observations can be made in regard to the corrosion rate data.

- The results of the tests performed in flowing water indicate that as the oxalic acid concentration is increased relative to the citric acid concentration, the corrosion rate decreased. The formation of the ferrous oxalate film is likely responsible for the inhibition at higher oxalic acid concentrations.

- There is good agreement between the corrosion rate data reported in References 12 and 19. Unfortunately a complete comparison cannot be made since the composition of the solution in Reference 12 is unknown and the solution also contains other constituents.

- The data in Reference 12 suggests that the corrosion rates for the oxalic/citric acid mixture are slightly less than those for oxalic acid. Therefore, the metal loss due to corrosion would be expected to be on the same order of magnitude as that for the oxalic acid.

- At a constant concentration, the corrosion rate appears to strongly increase with temperature. This result is similar to that for the citric acid. The exception appears to be the flowing water tests where the scatter in the data does not allow for conclusions to be drawn.

- Given that the chemical cleaning process will involve some degree of agitation, it would be beneficial to be able to compare the corrosion results from bench scale sludge dissolution tests with the oxalic acid versus those with the oxalic/citric acid mixture. Although Reference 12 suggests that coupons were immersed during bench scale tests, metal loss from the coupon was not determined. 
Table 4.6.2.3. Oxalic and Citric Acid Corrosion

\begin{tabular}{|c|c|c|c|c|c|c|}
\hline Type of Test & $\begin{array}{l}\text { Steel (wt.\% } \\
\text { carbon) }\end{array}$ & $\begin{array}{c}\text { Solution } \\
\text { Concentration } \\
\text { (M) }\end{array}$ & $\begin{array}{c}\text { Temperature } \\
\left({ }^{\circ} \mathrm{C}\right)\end{array}$ & $\begin{array}{c}\text { Test } \\
\text { Duration } \\
\text { (hours) }\end{array}$ & $\begin{array}{c}\text { Corrosion } \\
\text { Rate x } 10^{-5} \\
\text { (inches/hour) }\end{array}$ & Reference \\
\hline \multirow{3}{*}{ Coupon } & \multirow{3}{*}{0.06} & \multirow{3}{*}{$\begin{array}{l}\text { Oxalic: } 0.093 \\
\text { Citric: } 0.049\end{array}$} & 20 & \multirow{3}{*}{$\frac{46}{6}$} & 0.14 & \multirow{3}{*}{1} \\
\hline & & & 80 & & 0.31 & \\
\hline & & & Boiling Point & & 1.21 & \\
\hline \multirow{4}{*}{$\begin{array}{l}\text { Coupon in } \\
\text { flowing water } \\
-6 \mathrm{~cm} / \mathrm{s}\end{array}$} & \multirow{4}{*}{ Max. 0.25} & Oxalic: 0.0022 & 90 & \multirow{4}{*}{22} & NA & \multirow{4}{*}{16} \\
\hline & & Citric: 0.0014 & 117 & & $35.1 \pm 23.4$ & \\
\hline & & Oxalic: 0.0044 & 90 & & $19.5 \pm 3.9$ & \\
\hline & & Citric: 0.0014 & 117 & & $11.7 \pm 15.6$ & \\
\hline \multirow{9}{*}{$\begin{array}{l}\text { Coupon tests } \\
\text { in Decon } \\
4518^{*}\end{array}$} & \multirow{9}{*}{ Max. 0.3} & \multirow{3}{*}{4 wt. $\%$} & 75 & 336 & 0.21 & \multirow{9}{*}{12} \\
\hline & & & 85 & 168 & 0.57 & \\
\hline & & & 95 & 168 & 0.73 & \\
\hline & & \multirow{3}{*}{8 wt. $\%$} & 75 & 336 & 0.31 & \\
\hline & & & 85 & 168 & 0.57 & \\
\hline & & & 95 & 168 & 0.80 & \\
\hline & & \multirow{3}{*}{12 wt. $\%$} & 75 & 336 & 0.33 & \\
\hline & & & 85 & 168 & 0.57 & \\
\hline & & & 95 & 168 & 0.86 & \\
\hline
\end{tabular}

* Decon 4518 a proprietary blend of oxalic, citric, and tartaric acids with a corrosion inhibitor and surfactants. The molar concentrations of each acid are unknown.

\subsubsection{Conclusions}

We observed low general corrosion rates in tests in which carbon steel coupons were contacted with solutions of oxalic acid, citric acid and mixtures of oxalic and citric acids. Wall thinning can be minimized by maintaining short contact times with these acid solutions. Development of these acids as cleaning solutions requires selection of acid concentrations and temperatures that maximize cleaning power while minimizing corrosion rate. 


\subsection{CONCLUSIONS AND RECOMMENDATIONS}

Testing results showed the following:

- Dissolution of simulated HM and PUREX sludges with oxalic and citric acid mixtures at SRTC confirmed general trends reported previously by Russian testing.

- Unlike the previous Russian testing six sequential contacts of a mixture of oxalic acid citric acids at a 2:1 volume ratio of acid to sludge did not produce complete dissolution of simulated HM and PUREX sludges.

- We observed that increased sludge dissolution occurred at a higher acid to sludge volume ratio, 50:1, compared to the recommended ratio of 2:1.

- We observed much lower dissolution of aluminum in a simulated HM sludge by sodium hydroxide leaching. We attribute the low aluminum dissolution in caustic to the high fraction of boehmite present in the simulated sludge.

- Dissolution of HLW sludges from Tank 8F (PUREX) and 12H (HM) with 4 wt \% oxalic acid and oxalic/citric acid followed general trends observed with simulated sludges. The limited testing suggests that a mixture of oxalic and citric acids is more efficient for dissolving HM and PUREX sludges and provides a more homogeneous dissolution of HM sludge than oxalic acid alone.

- Dissolution of HLW sludges in oxalic and oxalic/citric acid mixtures produced residual sludge solids that measured higher neutron poison to equivalent ${ }^{235} \mathrm{U}$ weight ratios than that in the untreated sludge solids. This finding suggests that residual solids do not present an increased nuclear criticality safety risk.

- Generally the neutron poison to equivalent ${ }^{235} \mathrm{U}$ weight ratios of the acid solutions containing dissolved sludge components are lower than those in the untreated sludge solids. We recommend that these results be evaluated further to determine if these solutions contain sufficient neutron poisons.

- We observed low general corrosion rates in tests in which carbon steel coupons were contacted with solutions of oxalic acid, citric acid and mixtures of oxalic and citric acids. Wall thinning can be minimized by maintaining short contact times with these acid solutions.

We recommend additional testing with oxalic and oxalic/citric acid mixtures to measure dissolution performance of sludges that have not been previously dried. This testing should include tests to clearly ascertain the effects of total acid strength and metal complexation on dissolution performance. Further work should also evaluate the downstream impacts of citric acid on the SRS High-Level Waste System (e.g., radiochemical separations in the Salt Waste Processing Facility and addition of organic carbon in the Saltstone and Defense Waste Processing facilities). 
This page was intentionally left blank 


\subsection{REFERENCES}

${ }^{1}$ R. Lubtsev and Y. Revenko, "V. G. Khlopin Radium Institute and Mining Chemical Combine Final Report for the Project Russian Chemical Decontamination of Tanks (Phase 2)", St. Petersburg, 2000.

${ }^{2}$ D. T. Hobbs and M. E. Stallings, "Test Plan for the Evaluation of Chemical Cleaning Solutions with Savannah River Site High Level Waste Sludges", WSRC-RP-200000356, Rev 0, March 7, 2001.

${ }^{3}$ R. F. Bradley and A. J. Hill, Jr., "Chemical Dissolution of Sludge from a High Level Waste Tank at the Savannah River Plant," DP-1471, November 1977.

${ }^{4}$ D. T. Hobbs, "Precipitation of Uranium and Plutonium from Alkaline Salt Solutions," Nuclear Technology, 1999, 128, 103-112.

${ }^{5}$ Weber, E. J., "Aluminum Hydroxide Dissolution in Synthetic Sludges", DP-1617, March 1982.

${ }^{6}$ R. Lubtsev, E. M. Kostin and V. P. Popik, “ V. G. Khlopin Radium Institute and Mining Chemical Combine Final Report for the Project Sludge Dissolution and Chemical Cleaning of Tanks with Use of Oxalic and Other Chemicals (Phase 1)," St. Petersburg, 1998.

${ }^{7}$ Wefers, K.; Bell, G. M. Oxides and Hydroxides of Aluminum; Alcoa Technical Paper No. 19, Revised; Aluminum Company of America; East St. Louis, IL, 1972.

${ }^{8}$ A. E. Martell and R. K. Smith, Critical Stability Constants Volume 3: Other Organic Ligands, Plenum Press, New York, 1977.

${ }^{9}$ J. R. Wiley, "Solubility of Simulated Sludges in Oxalic Acid," DPST-78-489, September 5, 1978.

${ }^{10}$ M. R. Poirier and S. D. Fink, "Investigation of Alternative Approaches for Cleaning Mott Porous Metals Filters," WSRC-TR-2002-00526, Rev. 0, November 12, 2002.

${ }^{11}$ Complex Compounds of Uranium, I. I. Chernyaev, Ed., Academy of Sciences of the U.S.S.R., translated by L. Mandel, Israel Program for Scientific Translations, Ltd., 1966.

${ }^{12}$ R. S. Ondrecjin, "Carbon Steel and Stainless Steel Attack from Sludge Dissolution", DPST-76-471, December 15, 1976.

${ }^{13}$ M. C. H. Fong, "Oxalic Acid Cleaning of Tank 24H", DPST-85-782, September 9, 1985.

${ }^{14}$ E. W. Wilde, et.al., "Cleaning Agents for Reactor Heat Exchangers”, DP-1670, March, 1984.

${ }^{15}$ H. D. Smith, R. L. Russell, and G. K. Patello, "Evaluation of Hydrogen Gas Generation from Oxalic Acid Contact with the Carbon Steel of a High Level Waste Storage Tank", in Environmental Issues and Waste Management Technologies in the Ceramic and Nuclear Industries, Eds. J. C. Marra and G.T. Chandler, Ceramic Transactions, Vol. 93, pp. 221-227, 1999.

${ }^{16}$ R. A. Speranzini, et. al., Materials Performance, pp. 67-72, February 1989.

${ }^{17}$ L. Chen, et. al., "A Survey of Decontamination Processes Applicable to DOE Nuclear Facilities", ANL-97/19, pp. 27-28, 1997.

${ }^{18}$ D. B. Bechtold, "Study of Radionuclide Leaching from the Residues of K Basin Sludge 
Dissolution”, HNF-2917, July 30, 1998.

${ }^{19}$ M. R. Elmore, et. al., "Fiscal Year 1995 Laboratory Scale Studies of Cs Elution in Tank 8D-1 and Sludge Dissolution in Tank 8D-2”, PNNL-10945, April 1996.

${ }^{20}$ M. R. Elmore, "Corrosion of Mild Steel in Simulated Cesium Elution Process Solutions", PNNL-11284, September 1996.

${ }^{21}$ M. S. Abdel Aal, et. al., Materials, Chemistry and Physics, Vol. 39, pp. 290-297, 1995.

${ }^{22}$ Kirk-Othmer Encyclopedia of Chemical Technology, Vol, 6, 4 ed. 1993, p. 354. 